\title{
THE NEW FACE OF SCHOOL DESEGREGATION
}

\author{
KRISTI L. BOWMAN
}

\section{INTRODUCTION}

In 1998, the balance tipped: for the first time, Latinos and Latinas $^{1}$ comprised a greater percentage of the national school-age population than did African Americans. ${ }^{2}$ Within forty years, Whites will become a statistical minority in the United States' school-age population $^{3}$ - and in an increasing number of public school districts. ${ }^{4}$ In Hawaii, New Mexico, and California, this population shift has occurred

Copyright $@ 2001$ Kristi L. Bowman.

1. A note on terminology: first, I view racial and ethnic categorizations as proper nouns and will capitalize them as such; second, I choose to use "Latino" rather than "Hispanic" to emphasize the contemporary place of origin rather than the conquerors of several centuries gone by; third, although I would prefer to use "Latino/a" rather than the supposedly neutral but also masculine "Latino" when discussing both males and females, I have chosen to use "Latino" to minimize distraction from the substance of my argument. For further discussion of issues of nomenclature, see, e.g., U.S. District Judge Seals's opinion in Cisneros v. Corpus Christi Independent School District, 324 F. Supp. 599, 606-07 (S.D. Tex. 1970) (describing the "naming for identification" phenomenon) and Ian F. Haney López, Retaining Race: LatCrit Theory and Mexican American Identity in Hernandez v. Texas, 2 HARv. LATINO L. REV. 279, 279 n.1 (1997) (capitalizing racial designations and employing the term "Latino/a").

2. Mary Ann Zehr, Un Dia Nuevo for Schools, EdUC. WK., Nov. 8, 2000, at 39. The United States Census Bureau estimates that Latinos will be the United States' largest NonWhite racial and ethnic group by 2005. U.S. Census Bureau, Population Projections Program, Population Division, Projections of the Resident Population by Race, Hispanic Origin, and Nativity: Middle Series, 2001 to 2005, at http://www.census.gov/population/projections/nation/ summary/np-t5-b.txt (Jan. 13, 2000) (on file with the Duke Law Journal).

3. Minority Groups to Emerge As a Majority in U.S. Schools, EDUC. WK., Sept. 27, 2000, at 34 [hereinafter Minority Groups]. Whites will be a minority in the United States population by 2060. U.S. Census Bureau, Population Projections Program, Population Division, Projections of the Resident Population by Race, Hispanic Origin, and Nativity: Middle Series, 2050 to 2070, at http://www.census.gov/population/projections/nation/summary/np-t5-g.txt (Jan. 13, 2000) (on file with the Duke Law Journal).

4. See Minority Groups, supra note 3, at 34 ("[D]emographers project that all but two states-Arkansas and Mississippi-will see an increase in their minority [student] enrollments between now and 2015."). 
already. ${ }^{5}$ Texas will have a Non-White majority around 2015, and Arizona, New York, Nevada, New Jersey, and Maryland will quickly follow. ${ }^{6}$ The rapidly changing racial and ethnic demographics of our country might seem surprising not only because a Non-White majority is anticipated within the next sixty years, but also because so much of the growth will occur in the Latino population. The 2000 United States Census shows that the percentage of respondents identifying themselves as Latino increased 60\% since 1990 and that Latinos will be the United States' largest minority group even sooner than expected.

American society operates in a paradigm in which an individual is a member of the "majority" or the "minority," either White or Non-White. As a group, Latinos are nearly invisible within this paradigm because Non-White often is presumed to be roughly equivalent to African American. This invisibility is readily apparent in contemporary school desegregation law: it is not only law students and lawyers who know that Brown v. Board of Education ${ }^{8}$ was about African American schoolchildren in Topeka, Kansas. The perception of Brown and its progeny as occurring in a society where there are two races, Black and White, is widely shared. This Black-White binary has influenced courts' and legislatures' race-conscious remedies such as school desegregation orders and employment discrimination claims. When those remedies originated in the 1960s, they reflected a population that was nearly $90 \%$ White, including an estimated $4 \%$ Latino, and $10 \%$ African American.

Although plaintiffs brought successful challenges to Latino segregation in public schools before Brown cemented the idea that "separate educational facilities are inherently unequal,", the Court

5. See, e.g., Mike Davis, Magical Urbanism: Latinos Reinvent the U.S. City 1 (2000) (noting California's demographic shift); Ian F. Haney López, Race, Ethnicity, Erasure: The Salience of Race to LatCrit Theory, 10 LA RAZA L.J. 57, 123 (1998) (discussing Hawaii and New Mexico's demographic shift).

6. López, supra note 5, at 123.

7. D'Vera Cohn \& Darryl Fears, Hispanics Draw Even with Blacks in New Census, WASH. Post, Mar. 7, 2001, at A1. Because race and ethnicity are separate questions on the census, some individuals who self-identify as racially African American could also self-identify as Latino. However, only $1.7 \%$ of African American respondents also indicated that they are a member of another racial group, thus making it less likely that a significant number of individuals designated themselves both racially African American and ethnically Latino. Id.

8. 347 U.S. 483 (1954).

9. See Deborah Ramirez, Multicultural Empowerment: It's Not Just Black and White Anymore, 47 STAN. L. REV. 957, 958-59 (1995) (citing the 1960 United States Census).

10. 347 U.S. at 495. 
made no mention of those cases, or any reference to Latinos, in its 1954 decision. Brown ushered in an era of viewing school desegregation in a Black-White binary. It was not until almost two decades later, in 1973, that the framework changed.

In Keyes v. Denver, ${ }^{11}$ the Court endorsed the White-Non-White paradigm by deciding that it would classify Latinos with African Americans for purposes of school desegregation. Since 1973, the changing racial composition of the United States and of public schools has resulted in many courts' balancing schools ${ }^{12}$ according to a White-Non-White paradigm that ignores the full spectrum of racial and ethnic difference and presumes that Non-White groups are fungible for purposes of racial and ethnic balance. ${ }^{13}$ The White-NonWhite paradigm is injurious to Brown's intent, because instead of promoting equality, it promotes the dominance of whiteness. "White" becomes the singular point of reference for all other races; if one is not White, the "other" race to which one belongs is immaterial. White dominance and privilege remain unquestioned when "White" is the standard against which all else is defined. This White norm has been particularly harmful to Latinos, whose history has been marginalized even more than that of African Americans. ${ }^{14}$ This approach to balancing schools is not only intellectually imprecise, but also it denies Latinos the full benefits of school desegregation.

Some Latino and Asian American scholars have discussed their strong feelings of identification with the African American civil rights struggle. ${ }^{15}$ Similarly, Asian Americans have joined as plaintiffs in a

11. 413 U.S. 189 (1973)

12. In the remedy phase of school desegregation litigation, courts commonly require that schools throughout the district contain numbers of White and Non-White students roughly proportional to the respective percentage of White and Non-White students in the district. This practice is generally known as balancing schools along the lines of the race and ethnicity of students.

13. For recent examples, see infra notes 207-11 and accompanying text.

14. See Stephanie L. Phillips, The Convergence of the Critical Race Theory Workshop with LatCrit Theory: A History, 53 U. MiAMI L. REV. 1247, 1251-53 (1999) (discussing the dominance of the African American historical and contemporary narrative even within the Critical Race Theory movement in the early 1990s, and the corresponding emergence of LatCrit theory); infra notes 288-297 and accompanying text (surveying treatment of Latinos in legal education).

15. See, e.g., Enrique (Henry) T. Trueba, Latinos Unidos: From Cultural DIVERSITY TO THE POLITICS OF SOLIDARITY 18 (2000) (arguing that "[t]he training ground for political organization in Latino communities was the Civil Rights Movement of the 1960s and 1970s"); Mari Matsuda, Beyond and Not Beyond Black and White: Deconstruction Has a Politics, in Critical RaCe Theory: Histories, Crossroads, Directions (Jerome McCristal 
number of equal protection cases brought by African Americans, such as Loving $v$. Virginia. ${ }^{16}$ These Non-White groups have benefited from the rhetoric of the African American civil rights struggle and from the legal achievements of that movement. ${ }^{17}$ In the context most relevant to this Note, school desegregation litigation, Latinos and African Americans both must be integrated with White students. This Note discusses the importance of Latinos in school desegregation efforts past and present caused by the already substantial and rapidly growing Latino population in the United States. Latinos are an important constituency nationwide and, specifically, in many school districts with outstanding desegregation decrees. However, many of the ideas discussed here are not exclusive to Latinos. The concepts have parallels to other racial and ethnic groups. For example, in parts of California and New York where large concentrations of Asian Americans reside, Asian Americans' experiences are similar to, but certainly should not be assumed to be identical to, Latinos' experiences more generally. ${ }^{18}$

Part I of this Note analyzes how the Latino identity has been socially constructed inside ever-changing concepts of race and ethnicity as well as inside the Black-White binary. This construction has been strongly influenced by various branches of the federal government, which have attempted to define the Latino identity in inconsistent, often conflicting ways. Part II reviews the widely neglected history of Latino school segregation and resistance to that segregation through litigation, focusing on Mendez v. Westminster, ${ }^{19}$ a precursor to Brown. Part III analyzes the contemporary framework for school desegregation: the White-Non-White paradigm that conflates Latino and African American identities. Under the guise of providing equal educational opportunity, this new paradigm simultaneously disadvantages both groups and perpetuates the White norm. Finally, Part IV pro-

Culp, Jr. et al. eds., forthcoming 2001) (noting common ties between the Asian American and African American civil rights movements).

16. 388 U.S. 1 (1967).

17. Professor Matsuda recounts this bond: "We were children in Los Angeles when Black nationalist graffiti first started appearing on the walls and we heard phrases like "Black is beautiful.' For Asian Americans, this remarkable inversion meant yellow was also possibly beautiful." Matsuda, supra note 15.

18. See generally Robert CHANG, Disoriented: Asian AMERICANS, LAW, AND THE NATION-STATE 11-26 (1999) (discussing the construction of the Asian American identity within the Black-White binary).

19. 64 F. Supp. 544 (S.D. Cal. 1946), aff'd, 161 F.2d 774 (9th Cir. 1947). 
poses a range of measures that can be taken to alleviate the marginalization of Latinos in the context of school desegregation.

\section{CONSTRUCTION OF THE LATINO IDENTITY}

To understand the ways society acts upon a group of individuals to create their identity as Latinos, it is first necessary to examine the means through which race and ethnicity are constructed. The BlackWhite binary pervades the contemporary American discourse about race. The Latino identity has been created in this binary-a binary in which it has no easy fit. The ever-changing classification of Latinos in the United States' decennial census illustrates the difficulty of this fit. It is important to understand the inconsistent nature of the Latino identity before turning directly to a discussion of school desegregation. This inconsistent nature has specifically informed past attempts by Latinos to challenge school segregation, and it continues to influence the present treatment of Latinos in the context of school desegregation litigation.

\section{A. Construction of Race, Ethnicity, and the Black-White Binary}

The concept of race in the English language can be traced back to the sixteenth century, where it originally served as a demarcation of common ancestors. ${ }^{20}$ Not until the late eighteenth century did race come to be understood as indicating immutable, biological differences. ${ }^{21}$ Today, the concept of race remains powerful because of the claim that race has biological bases. ${ }^{22}$ However, the fluidity of assignment to a particular racial group can be seen across continents and centuries. In the early American colonial period, an individual's race, as perceived by others, was strongly influenced by his or her wealth. ${ }^{23}$ The same is true in contemporary Brazilian society. ${ }^{24}$ When racial classification is demanded yet race is increasingly unclear, ${ }^{25}$ the results

20. 13 OXFORD ENGLISH DICTIONARY 69 (2d ed. 1989).

21. Id.; see also Neil Gotanda, A Critique of "Our Constitution is Color-Blind," 44 STAN. L. REV. 1, 28 (1991) (discussing the historical treatment of race as a fixed trait).

22. Martha R. Mahoney, Segregation, Whiteness, and Transformation, 143 U. PA. L. REV. 1659,1661 (1995).

23. See Gotanda, supra note 21, at 32 ("[S]laveholders developed a complementary ideological structure of racial categories that served to legitimate slavery.").

24. See id. at 31 (describing the fluidity of racial labels in Brazilian society).

25. See Richard J. Payne, Getting Beyond Race: The Changing American CULTURE 138 (1998) ("Racially categorizing people from throughout the world is fast becoming almost impossible."). 
can be troublesome: "Public schools struggle with trying to fit multiracial children into official racial categories. Some administrators, like census personnel, arbitrarily classify children."26

Race is now understood by many to be socially constructed rather than biologically based. ${ }^{27}$ The social construction of race means that one's skin color and other physical characteristics, which may serve as general indicators of someone's "race," do not have inherent meaning. For example, Whites are not inherently "smarter" than African Americans. ${ }^{28}$ However, in the words of Professor Ian Haney López, this lack of inherent biological meaning "does not diminish in any way [race's] social power or permanence." ${ }^{29}$ Race gains meaning through social practices that assign value based upon skin color and other physiological characteristics. ${ }^{30}$ For purposes of this Note, I interpret race as a combination of the shared social treatment experienced by a group defined largely by their physical characteristics, and the tangible results of those assumptions, such as a group's general socioeconomic position.

The foundation for Americans' understanding of race is rooted in both the United States' history of slavery and the Jim Crow laws and segregation that followed radical Reconstruction. ${ }^{31}$ Professor Richard Payne describes this contemporary conception of race as historically "based on the unusually sharp and rigidly fixed division between black and white, which is designed to keep the two groups

26. Id.

27. Professor López notes that "[t]he notion that race is biological is now widely recognized as a patent falsehood, an injurious myth deserving emphatic repudiation." López, supra note 5, at 99. Professor Juan Perea elaborates on this statement, noting that "[t]he idea that knowledge is socially constructed, and therefore both contingent upon the values of a society and highly formative of those values in subsequent generations, is now well established as a premise of critical theory." Juan F. Perea, The Black/White Binary Paradigm of Race: The "Normal Science” of American Racial Thought, 85 CAL. L. REV. 1213, 1219 n.27 (1997).

28. For refutation of the assumptions about race and intelligence in RICHARD J. Hernstein \& CHARles Murray, THE Bell Curve: InTElligenCE AND Class STRUCTURE IN AMERICA (1994), see generally THE BELl CURVE DEBATE: History, Documents, OPINIONS (Russell Jacoby \& Naomi Glauberman eds., 1995) (collecting more than seventy scholars' criticisms of The Bell Curve). See also Jeffrey Rosen \& Charles Lane, The Sources of The Bell Curve, in CRITICAL White Studies: LOOKING BeHIND THE MiRRor 529, 529-30 (Richard Delgado \& Jean Stefancic eds., 1997) [hereinafter CRITICAL WHITE STUDIES] (critiquing the sources and data upon which The Bell Curve relied).

29. López, supra note 5, at 99.

30. Id. at 100 ("Though a social construction, race is real. Its reality lies in social practices, including beliefs in natural group divisions and their significance, not in the abstract 'truth' of such beliefs.").

31. See PAYNE, supra note 25, at 136. 
separate and unequal." ${ }^{32}$ Similarly, Professor Richard Delgado develops an illustrative fictional dialogue in which one character claims: "the classic, the essential racial group is black.... When someone mentions 'civil rights,' you immediately think black., ${ }^{, 33}$ The BlackWhite binary as a way of conceptualizing race dominates not only legal scholarship, ${ }^{34}$ but scholarly books about White racism, ${ }^{35}$ law school texts, ${ }^{36}$ and-perhaps most importantly-such vehicles of popular culture as media and film. ${ }^{37}$ This binary gives due attention to the experiences of African Americans, but it results in the marginalization, and even invisibility, of other groups, including Asian Americans, Native Americans, and Latinos. ${ }^{38}$

While the concept of race is centuries old, the American idea of ethnicity dates back only to the early 1940 s. ${ }^{39}$ While race has been commonly connected with physical characteristics, ethnicity has been limited to cultural factors such as language, religion, and tradition. ${ }^{40}$ The characteristics that constitute an ethnicity can be defined either by the members of a group or by outsiders. ${ }^{41}$ Like race, ethnicity is mutable, as evidenced by its different construction in countries around the world. In some countries, race is "a dimension of ethnicity, while for others ethnicity [is] a dimension of race." ${ }^{, 2}$ As Literature and Afro-American Studies Professor Werner Sollors notes, contemporary scholars have been unable to consider race and ethnicity two separate categories, because the distinction is not as simple as the

\footnotetext{
32. Id.

33. Richard Delgado, When Equality Ends: Stories About Race And RESISTANCE 118 (1999).

34. See, e.g., Juan F. Perea, Ethnicity and the Constitution: Beyond the Black and White Binary Constitution, 36 WM. \& MARY L. REV. 571, 573 (1995) (arguing that the Supreme Court has "encouraged an underinclusive, binary discourse about race"); Perea, supra note 27, at 122132 (discussing the critique of this binary according to Critical Race Theory).

35. Perea, supra note 27, at 1232-39 (analyzing literature on how White racism affects Blacks in particular).

36. See infra notes $288-96$ and accompanying text.

37. See Perea, supra note 34 , at 573 (describing the Black-White binary as depicted in popular media).

38. Perea, supra note 27 , at 1220.

39. Werner Sollors, Foreword: Theories of American Ethnicity, in THEORIES OF ETHNICITY: A Classical READER, at x, x (Werner Sollors ed., 1996); see also 5 OXFORD ENGLISH DICTIONARY, supra note 20, at 424 (illustrating the changing use of "ethnicity" in the English language through examples).

40. López, supra note 5, at 289 .

41. Perea, supra note 34 , at 575 .

42. Clara E. Rodríguez, Changing Race: Latinos, The Census, and the History OF ETHNICITY IN THE UNITED STATES 36 (2000).
} 
suggestion that race is nature and ethnicity is culture. ${ }^{43}$ The boundaries between the two imperfect designations were never clear and, at the beginning of a new century, are becoming increasingly blurred. ${ }^{44}$

Recognizing the social construction of race and ethnicity renders the two concepts suspiciously similar as demarcations of group identity and accounts for the definitional overlap. What is gained from discussing race and ethnicity as separate constructs is a recognition that they have been "deployed in fundamentally different ways." 45 Thus, while two ethnic groups can be White, and thus share the presumption of innate similarity, racial difference has led to the conclusion that the racially Non-White group is innately inferior. ${ }^{46}$

Professor Juan Perea suggests two ways in which the connection between race and ethnicity has been misunderstood. ${ }^{47}$ First, ethnicity has been viewed as merely part of race, as in the case of a Latino juror who was struck because he was bilingual-a cultural and ethnic characteristic, but one the court viewed as a racial trait. ${ }^{48}$ Indeed, a not-insignificant number of people with Latino heritage cannot speak Spanish. Second, ethnicity is assumed to be irrelevant because race is the primary measure of classification. This assumption disregards the reality that people of different races can be part of the same ethnic group, both within and outside a particular country. ${ }^{49}$ Two Latinas who share the same Mexican American mother but have different fathers, one White, one African American, each could be considered Latina, even though their racial heritage is different. Additionally, the concepts of race and ethnicity should not be confused with national identity. Racially, White South Africans can have radically different physical characteristics than Black South Africans. The effects of those physical differences are clear from the different treatment re-

43. Sollors, supra note 39, at xxxiv.

44. Roger Clegg, Census Sense and Nonsense, NAT'L REV. OnLINE, at http://www. nationalreview.com/contributors/cleggprint030701.html (Mar. 7, 2001) ("Race is a dubious construct, especially in America, where there is so much intermarriage and so many of us have mixed ethnicities.") (on file with the Duke Law Journal). This National Review article leads to a different conclusion regarding the consideration of race and ethnicity than I advance, but our agreement about the impracticability of the categories is significant.

45. López, supra note 5, at 283.

46. See id. at 291 (discussing treatment of those groups seen as "innately inferior" to Whites).

47. Perea, supra note 34 , at 596-603.

48. Id. at 596-97.

49. Id. at 600 . 
ceived by the two groups under apartheid. ${ }^{50}$ Ethnically, firstgeneration Americans with Korean heritage can have significantly different experiences in the United States because of their cultural identity than first-generation Americans with Swedish heritage. ${ }^{51}$

Scholars refer to Latinos as both a racial and an ethnic group, ${ }^{52}$ but trying to classify Latinos in only one category (race or ethnicity) illustrates the problematic nature of the categories themselves. If Latinos are viewed as a separate race in order to be "on par" with African Americans, then their ethnic identity will have been collapsed into their racial identity. Given the history of slavery and the continued "demarcation line of skin color" that have created the BlackWhite racial binary ${ }^{53}$ there is little room within the racial framework for a distinct Latino racial category. Alternatively, if Latinos are viewed only as an ethnic group, then to fit within the larger BlackWhite binary they must also be assigned to one of the two racial groups. As will be discussed later, the Census Bureau has taken this approach, classifying Latinos as racially White in every decennial

50. For a captivating (and true) description of the struggles of Black South African lawyers and their relations with their White counterparts, see generally KENNETH S. BROUN, BLACK LAWYERS, WHITE COURTS: THE SOUL OF SOUTH AFRICAN LAW (2000).

51. Cultural beliefs may differ along the lines of gender roles and priorities such as work and family. For example, Asian societies and Asian Americans may harbor more "traditional" notions of power relations between men and women. See, e.g., AMY TAN, THE JOY LUCK ClUB (1990) (depicting the experiences of some Chinese American women). Scandinavians are known for being among the most progressive people worldwide in terms of women's equality, and this general social progressivism pervades areas of the United States that have a high concentration of Scandinavians, such as Minnesota, and is evident in Minnesota's support of presidential candidates. Minnesota's electoral votes have gone to the Democratic candidate for the past seven presidential elections, including President Reagan's landslide victory in 1984. Calling All Swing States: Endgame, NewsweEK, Nov. 20, 2000, at 110; Presidential Results Summary for All States, at http://cnn.com/ELECTION/2000/results/president/index3.html. (last visited Apr. 19, 2001) (on file with the Duke Law Journal).

52. Eduardo Mendieta, The Making of New Peoples: Hispanizing Race, in HisPANICS/LATINOS IN THE UNITED STATES: ETHNICITY, RACE, AND RIGHTS 45, 49 (Jorge J.E. Gracia \& Pablo de Greiff eds., 2000) ("Hispanics are not a race, they are an ethnicity. One can argue that they do not even constitute an ethnicity, for an ethnicity consists of a set of social practices that can be discerned and distinctly drawn out."). Professor López agrees that Latinos have been raced, see infra note 81 and accompanying text, but in his theory this does not require viewing Latinos as a race. See López, supra note 5, at 97 ("Latino groups have not been as consistently racialized as others, for example Whites or African Americans. The Hispanic category, for example, is of particularly recent vintage.").

53. Raul Yzaguirre \& Charles Kamasaki, Comment on "The Latino Civil Rights Crisis: A Research Conference," Harvard University Civil Rights Project, at http://www.law.harvard.edu/ groups/civilrights/papers/comment/comment.html (last visited Apr. 25, 2001) (on file with the Duke Law Journal). 
census except the 1930 Census. ${ }^{54}$ The only way for Latinos to receive the full benefits of school desegregation is for the discourse to shift away from the restrictive Black-White ${ }^{55}$ and race-ethnicity binaries. As Professor Jerome Culp suggests, the most important category of social construction may not be the demarcation of race, ethnicity, or nationality, but that of "other." 56 The role of "other" connotes powerlessness, and it is not necessary to distinguish among race, ethnicity, and nationality if one is in a marginalized group. The classification of Non-White embodies otherness.

\section{B. Construction of the Latino Identity: Social Experiences and the Census}

While abstract conceptions of race have existed for centuries, the origin of a common Latino identity is uncertain. As employed in contemporary American society, the Latino group label generally applies to those with Central American, South American, or Caribbean heritage. Though the use of the term "Latino" has been criticized as overly broad $^{57}$ and arguably repeats the same sort of essentialization I seek to avoid through deconstructing the White-Non-White para-

54. See infra notes 89-96 and accompanying text (detailing, in part, the limited racial categories used in the census).

55. Perea, supra note 27, at 1215.

56. Jerome McCristal Culp, Jr., Latinos, Blacks, Others, and the New Legal Narrative, 2 HARV. LATINO L. REV. 479, 479 (1997).

57. It is unlikely that people with Spanish (European) heritage would be assumed to belong to this amorphous group. Eduardo Mendieta provides a powerful critique of this generalization implicit in the word "Hispanic." His comments are equally applicable to the generalization inherent in the term "Latino":

Hispanics are said to be all persons of Latin American descent, who have been in the United States for several generations, or who might have arrived yesterday. They are said to speak Spanish, although many do not. Some are immigrants, while others are political refugees. Some could come from Latin American countries, although it is not clear whether Spaniards and Brazilians could be considered Hispanic. It is also not clear whether Blacks, descendants of slaves from the Caribbean and many Latin American countries with sizable black populations, are either Hispanics or Blacks. In short, the peoples that the label Hispanic hopes to embrace are too heterogeneous and diverse to be done justice by this rather homogenizing label. Furthermore, as Mary Romero has pointed out, the term Hispanic has contributed to the depoliticization of the history of each group subsumed under the label and it has deleteriously and even disrespectfully placed too much weight on the European elements of the traditions that inform the cultures of the peoples of Latin American descent.

Eduardo Mendieta, Becoming Citizens, Becoming Hispanics, in THE Good CITIZEN 123 (David Balstone \& Eduardo Mendieta eds., 1999). 
digm, ${ }^{58}$ my approach is to be, in Professor Stephanie Wildman's term, "strategically essentialist" structed inequality.

Latinos in the United States share many commonalties, illustrated by the shared social treatment of those labeled-and thus viewed-as Latinos, ${ }^{60}$ and by their economic position. ${ }^{61}$ The mutable, non-fixed nature of group identity is illustrated by the perception that Latinos who were not born in the United States must learn to perform the American Latino identity. ${ }^{62}$ Despite variations in the "education levels, income, and political power" that may distinguish Chicanos, Puertoriqquenos, Cuban Americans, and those with Central or South American heritage, Latino students uniformly "face increasing levels of school segregation in all parts of the country."63

Additionally, Latinos are economically worse-off than the general population. In married-couple families with at least one person employed, Latinos have "the highest poverty rates and the lowest income levels, compared with both white and black families." average income is $\$ 10,000$ lower than the national average..$^{65}$ In 1996 , Latinos' income level was slightly below that of African Americans

58. See Stephanie M. Wildman, Reflections on Whiteness and Latina/o Critical Theory, 2 HARV. LATINO L. REV. 307, 310 (1997) (noting the danger of using a single name to refer to a diverse group).

59. See id. at 311 ("Naming Latinas/os, being strategically essentialist, instead of relying on the umbrella categories 'race' or 'people of color' can help us reveal the hierarchies that exist within the category race.").

60. See López, supra note 5, at 77 (remarking that the Hernandez opinion treats the existence of a distinct race as a local question to be answered by community attitudes).

61. Despite potentially different standards of living enjoyed by various subgroups of Latinos (e.g., Cuban Americans being more affluent than Mexican Americans), it is still helpful to generalize about Latinos' economic status. Even if some groups are more well off than others, Latinos as a whole are the most underprivileged group. Importantly, the extreme poverty of some Latino subgroups is not even offset by other, more affluent Latino sub-groups. For the U.S. Census Bureau's breakdown of income by Latino ethnic group in 1997, see U.S. Census Bureau, Table 2.1: March 1997 CPS: Earnings of Persons by Race-Ethnicity Age 15 and over, at http://www.census.gov/population/socdemo/hispanic/cps97/tab02-01.txt (Aug. 7, 1998) (on file with the Duke Law Journal).

62. Professor Mendieta explains this need to perform: "One arrives a Guatemalan, Salvadorean, Colombian, Cuban, Venezuelan, Peruvian, Costa Rican, or Dominican, and slowly, after painful experiences of oppression, marginalization, and isolation, starts to learn to become a Latino and Hispanic." Mendieta, supra note 52, at 47.

63. Amy Stuart Wells, Hispanic Education in America: Separate and Unequal, ERIC/CUE Digest No. 59, at http://www.ed.gov/databases/ERIC_Digests/ed316616.html (1989) (citing Gary Orfield, The Growth and Concentration of Hispanic Enrollment and the Future of American Education, presented at National Council of La Raza Conference, Albuquerque, New Mexico, July 1988) (on file with the Duke Law Journal).

64. RODRÍGUEZ, supra note 42, at 23.

65. Mendieta, supra note 57, at 127. 
and two-thirds that of Whites. ${ }^{66}$ Latinos' economic instability is illustrated by their having the lowest rates of home ownership and the highest percentage of income spent on housing, ${ }^{67}$ as well as their being less likely than Whites or African Americans to have health insurance or pensions. ${ }^{68}$ In 1998, Latinos' unemployment rate was $2.1 \%$ above Whites', but $1.9 \%$ below African Americans', implying that although Latinos have higher employment rates, they hold lower-paying jobs than African Americans. ${ }^{69}$ Given this economic position, it is not difficult to understand why Latinos are characterized as the new "veritable underclass" in American society, successors to a position held by African Americans for the past two hundred years. ${ }^{70}$

Latinos have been present in the United States in sizeable numbers since the mid-1800s, when Mexico ceded the lands composing California, Nevada, Arizona, New Mexico, and Utah to the United States at the conclusion of the Mexican-American War, in addition to recognizing the secession of Texas. ${ }^{71}$ Significant increases in the number of Latinos also occurred at the close of the nineteenth century when Puerto Rico was acquired ${ }^{72}$ in the mid-twentieth century when Mexican migration escalated, ${ }^{73}$ and in 1959 and the early 1960 s fol-

66. RODRÍGUEZ, supra note 42 , at 23.

67. Id.; Mendieta, supra note 52 , at 45 .

68. RoDRíGUEZ, supra note 42, at 23-24.

69. See U.S. Bureau of Labor Statistics, Employment Situation Summary, at http://www.bls. gov/news.release/empsit.nr0.htm (Jan. 2001) (reporting statistics describing the employment situation in the United States during December 2000) (on file with the Duke Law Journal). Additionally, the President's Advisory Commission on Educational Excellence for Hispanic Americans notes a disparity in employment rates between Latinos (men) and Latinas (women): "Hispanic American males (16 years and older) have a participation rate of 90.2 percent in the U.S. labor force. The Hispanic women's labor force participation rate of 58 percent is expected to increase to 80 percent by the year 2005." White House Initiative on Educ. Excellence for Hispanic Ams., Who are Hispanic Americans?, in Our Nation on the Fault Line: Hispanic American Education, at http://www.ed.gov/pubs/FaultLine/who.html (Sept. 1996) (on file with the Duke Law Journal).

70. Mendieta, supra note 57, at 128 .

71. See Margo J. Anderson \& Stephen E. Feinberg, Who Counts? The Politics OF CENSUS-TAKING IN CONTEMPORARY AMERICA 182 (1999) (noting that roughly 80,000 Hispanics resided in New Mexico and California when the United States annexed these lands); MARK CRAWFORD, ENCYClOPEDIA OF THE MEXICAN-AMERICAN WAR 16 (1999) (describing the annexation of Arizona); id. at 61 (describing the annexation of California); id. at 200 (describing the annexation of Nevada); id. at 201 (describing the annexation of New Mexico); id. at 282 (describing the annexation of Utah).

72. Berta Esperanza Hernandez-Truyol, Building Bridges-Latinas and Latinos at the Crossroads: Realities, Rhetoric, and Replacement, 25 COLUM. HuM. RTS. L. REV. 369, 383 n.48 (1994).

73. See id. at 388 ("Between 1900 and $1940 \ldots$ the numbers of Mexicans journeying to the United States began to increase."). 
lowing Fidel Castro's rise to power. ${ }^{74}$ Since then, Mexican and Cuban migrations have continued at significant rates. ${ }^{75}$ In $1999,20 \%$ of the approximately one million legal immigrants to the United States were from Mexico; many others were from other parts of Central and South America. ${ }^{76}$

Historically, Latinos' classification as White rather than as African American justified the admission of Mexicans as United States citizens after the Mexican-American War. The Treaty of Guadalupe Hidalgo ended the Mexican-American War in 1848 and stipulated that former Mexican citizens were to be given "all the rights of citizens of the United States." ${ }^{77}$ Despite the straightforward language of the treaty, Latinos in these areas struggled for American citizenship. ${ }^{78}$ When California gained statehood in 1850, its constitution allowed Latinos to become citizens by virtue of their whiteness. ${ }^{79}$ California courts followed their state constitution's lead, granting some Latinos the benefits of American citizenship - and then only because of their status as White males. ${ }^{80}$ Courts that assigned Latinos a White racial identity (or raced ${ }^{81}$ Latinos White) for purposes of determining citi-

74. White House Initiative on Educ. Excellence for Hispanic Ams., supra note 69.

75. See Hernandez-Truyol, supra note 72, at 390-92 (noting the continuing influx of Mexican immigrants and the three waves of Cuban immigrants since the late 1950s).

76. Mixed Needs of Immigrants Pose Challenges for Schools, EDUC. WEEK, Sept. 27, 2000, at 38 .

77. Treaty of Peace, Friendship, Limits, and Settlement with the Republic of Mexico, Feb. 2, 1848, U.S.-Mex., art. IX, 9 Stat. 922 (commonly known as the Treaty of Guadalupe Hidalgo). The treaty provided not only for a significant transfer of land from Mexico to the United States in the area now known as the American southwest, but also served as a measure of protection for the persons living on that land. It is printed in the Statutes at Large in both English and Spanish. Id.

78. See Juan F. Perea et Al., Race and Races: Cases and Resources for a DiVERSE AMERICA 260 (2000) (claiming that the President and Senate, despite the treaty language, were "unwilling[] to deal with Mexicans on terms of equal citizenship").

79. The California Constitution granted suffrage to "every white male citizen of the United States, and every white male citizen of Mexico, who shall have elected to become a citizen of the United States, under the treaty of [Guadalupe Hidalgo] . . . of the age of twenty-one years who shall have been a resident of the state six months next preceding the election." CAL. CONST. of 1849 , art. II, $\S 1$.

80. See, e.g., People ex rel. Kimberly v. De La Guerra, 40 Cal. 311, 339 (1870) (upholding full citizenship of a "white male [former] citizen of Mexico" while noting that other races, although still American citizens under the treaty, may be denied certain political rights, such as the franchise).

81. In recent years, "race" has been used as a verb connoting the assignment of racial identification (e.g., "Through its reasoning, the court raced Jan White.") in addition to the related traditional use of "race" as a noun (e.g., "Ryan's race is African American."). For examples of the use of "race" as a verb, see generally RACE-ING JUSTICE, EN-GENDERING POWER: ESSAYS on ANita Hill, Clarence Thomas, and the Construction of Social Reality (Toni Morrison ed., 1992); Katherine M. Franke, What Does a White Woman Look Like? Racing and 
zenship failed to recognize that Latinos did not have the social privileges that came with being White. Latino children often attended segregated schools; Latino neighborhoods were segregated from White neighborhoods; and Latinos suffered from employment discrimination. $^{82}$ This characterization of Latinos as White is an outgrowth of the legacy of slavery. African Americans were not guaranteed United States citizenship until the passage of the Fourteenth Amendment in 1868, yet to have classified Latinos as African American would have been difficult for nineteenth century courts, given the clarity of the two groups' different geographical origins.

The recognition of Whites' and Latinos' different societal experiences formed the crux of the Supreme Court's 1954 decision in Hernandez $v$. Texas, ${ }^{83}$ where the Court grappled with Latinos' racial identity for the first and last time. ${ }^{84}$ In Hernandez, a jury in Jackson County, Texas, convicted Pete Hernandez, a Latino, of murder. He challenged his conviction on equal protection grounds-because Latinos were "systematically excluded" from jury service in Jackson County, Hernandez claimed he had not been tried by a jury of his peers. ${ }^{85}$ The Court held that because Latinos constituted a "separate class" from Whites and African Americans in Jackson County, as demonstrated by "the attitude of the community," the systematic exclusion of Latinos from jury service violated the Fourteenth Amendment. ${ }^{86}$ Although the Court specifically rejected the idea of "only two

Erasing in Law, 74 TEX. L. REV. 1231 (1996); Judy Scales-Trent, Notes of a White Black Woman, reprinted in CRITICAL WHITE STUDIES, supra note 28, at 475, 476 ("'Race' is not something that just exists. It is a continuing act of imagination. It is a very demanding verb.").

82. George A. Martinez, African Americans, Latinos and the Construction of Race: Toward an Epistemic Coalition, 19 CHICANO-LATINO L. REV. 213, 215 (1998).

83. 347 U.S. 475 (1954).

84. López, supra note 5 , at 60.

85. Hernandez, 347 U.S. at 476-77.

86. Id. at 479. The Court further noted:

Here the testimony of responsible officials and citizens contained the admission that residents of the community distinguished between "white" and "Mexican." The participation of persons of Mexican descent in business and community groups was shown to be slight. Until very recent times, children of Mexican descent were required to attend a segregated school for the first four grades. At least one restaurant in town prominently displayed a sign announcing "No Mexicans Served." On the courthouse grounds at the time of the hearing, there were two men's toilets, one unmarked, and the other marked "Colored Men" and "Hombres Aqui" ("Men Here"). No substantial evidence was offered to rebut the logical inference drawn from these facts....

Id. at $479-80$. 
classes-white and Negro," ${ }^{87}$ its emphasis on racial and ethnic relations in Jackson County implies a preference for a case-by-case analysis that limits the Court's protection of Latinos to the specific community involved, rather than assuming that such classification triggers strict scrutiny generally. ${ }^{88}$ The Court did not conclude that Latinos were racially Non-White, but its holding reveals an acknowledgement of the differences between Whites and Latinos. The decision defines Whites and Latinos as distinct groups.

With one exception, the United States Census Bureau has raced Latinos White. As required by Article I, Section 2 of the United States Constitution, the decennial census has been conducted every ten years since $1790 .{ }^{89}$ Respondents to the 1930 Census were given the option to designate that they belonged to the "Mexican race," but due to objections by Mexican Americans, this racial category was removed. ${ }^{90}$ Since the 1940 Census, Latinos have been presumed racially White unless designated otherwise. ${ }^{91}$ In 1970, the census asked whether the respondent's ethnic identity was "Hispanic,", but this question reached merely $5 \%$ of respondents because it appeared only on the census long form. ${ }^{93}$ Since the 1980 Census, the Latino ethnicity question has been asked on the standard short form in addition to the race question, which respondents can now answer as White, Black, Asian or Pacific Islander, American Indian, or Other. ${ }^{94}$ In 1980, 40\%

87. Id. at 477 .

88. See, e.g., Korematsu v. United States, 323 U.S. 214, 219-20 (1944) (applying strict scrutiny, but finding that the classification was permissible); Strauder v. West Virginia, 100 U.S. 303, 310 (1880) (applying heightened scrutiny in a dispute based upon racial classification).

89. U.S. Census Bureau, American Factfinder, at http://factfinder.census.gov/home/en/ decennialdata.html (May 2000) (on file with the Duke Law Journal).

90. ANDERSON \& FEINBERG, supra note 71, at 182-83; see also RODRÍGUEZ, supra note 42, at 42 (describing changes in the U.S. Census).

91. RODRÍGUEZ, supra note 42, at 102.

92. ANDERSON \& FEINBERG, supra note 71, at 183.

93. Id.

94. RODRÍGUEZ, supra note 42, at 6-7.

The Multiracial Category Movement (MCM) was formed partly in response to the limited racial categories used by the census. For a description of the reasoning of the MCM's proponents, see generally Bijan Gilanshah, Multiracial Minorities: Erasing the Color Line, 12 LAW \& INEQ. 183 (1993) (describing the psychological and political motivations behind the efforts of multiracial Americans to set appropriate census categories). This movement attempts to create a wholly new racial designation, the multiracial category, in order to grapple with racial classification of the growing number of biracial and multiracial persons in the United States. The lines of physical appearance along which our society previously assigned race are becoming ever more blurred because of an increasing number of children resulting from interracial marriage and sexual relations. Id. at 185-88. But see Trina Jones, Shades of Brown: The Law of Skin 
of Latinos classified themselves not as racially White but as "Other," compared to $3 \%$ of the non-Latino population. ${ }^{95}$ Twenty years later in $2000,42 \%$ of the Latino population classified themselves as racially "Other," but only $.1 \%$ of the non-Latino population did the same. ${ }^{96}$

Although sociologist Clara Rodríguez notes that the Census appears to be evolving towards a White-Non-White paradigm, this change should not be seen as beneficial to Latinos. ${ }^{97}$ As will be discussed below, even though a White-Non-White paradigm may allow more space for the Latino narrative than the Black-White binary does, the White-Non-White paradigm used in school desegregation litigation collapses all Non-White identities and promotes White privilege. ${ }^{98}$ Furthermore, in the context of the U.S. Census, Latinos will likely continue to be raced White even though they do not have the social privileges of whiteness and in fact are the "poorest of the poor." 99

Even if viewed as an ethnic group, Latinos suffer from the effects of racism. Because of the differences in historical struggles, racism against Latinos has "a different genesis" than racism perpetrated against African Americans. ${ }^{100}$ Importantly, there often may be a difference in how Latinos conceive of their racial identity and how others perceive them. For example, Puerto Ricans who might be considered White by Caribbean standards could easily be considered Black by American standards. ${ }^{101}$ Latinos have discussed their experiences of being "informed" by non-Latinos about their place in the ill-fitting Black-White paradigm-some Latinos have been told that they are

Color, 49 DUKE L.J. 1487, 1521-27 (2000) (criticizing the arguments in support of the Multiracial Category Movement).

95. RODRÍGUEZ, supra note 42, at 130.

96. U.S. Census Bureau, USA Statistics in Brief-1990 and 2000 Census Race and Hispanic Data, available at http://www.census.gov/statab/www/part1a.html (last visited Apr. 30, 2001) (on file with the Duke Law Journal).

97. See RodríGUEZ, supra note 42, at 17:

An analysis of U.S. decennial census classifications shows the clear historical progression toward a more definitive bipolar structure .... evolution of two fundamental and socially constructed polarities that place "whites" at one end and "other social races" at the other.... It is with this historically evolved bipolar structure that groups who have not been "quite white" or "quite black" have contended in the past, and it is in this structure that Latinos and other groups are entangled today.

98. See infra notes 231-42 and accompanying text.

99. Mendieta, supra note 52, at 45; see also supra notes 64-70 and accompanying text (analyzing the relative poverty of Latinos in America, as compared with the U.S. population as a whole).

100. Perea, supra note 27, at 1253.

101. PAYNE, supra note 25, at 138-39. 
White, and some have been told that they are Black. ${ }^{102}$ These acts of assigning a racial identity to Latinos reveal that Latinos are not raced even consistently. ${ }^{103}$

This inconsistency is illustrated by an assumption that the U.S. Census Bureau has perpetuated-that Latinos are racially White. This leads directly to what Professor Richard Delgado labels the "other white" strategy, a "logical extension of the kind of thinking the black-white binary disposes you to." ${ }^{104}$ The "other white" strategy permits some people to believe that because a Latino is raced White, he or she cannot be the subject of discrimination. ${ }^{105}$ When a White person views a Latino as White, the White person may be less sympathetic to the Latino's claims of social injustice because, after all, the Latino is White-not African American. ${ }^{106}$ If an African American person views a Latino as White, this might cause further resentment because of the Latino's perceived goal of being treated as though he or she is White. ${ }^{107}$ The discussion of what happens when Latinos are viewed as White is not generally applicable, though, because Latinos are primarily viewed as other than White, not as other Whites. ${ }^{108}$ This situation illustrates once again Professor Juan Perea's observation that "Latinos do not fit the boxes supplied by the paradigm." 109

For purposes of determining their citizenship in the late nineteenth century, state courts told Latinos they were White. In 1954 in Hernandez, the Supreme Court suggested that Latinos were a protected class, distinct from Whites. In non-legal discourse, Latinos

102. Clara Rodríguez relates the experiences of some of her Latino students:

Latino students have also told me that non-Latinos sometimes assume they are African American. When they assert they are not "black" but Latino, they are either reproved for denying their "race" or told they are out of touch with reality. Other Latinos, who see whites as other-than-me, are told by non-Latinos, "But you're white." Although not all Latinos have such dramatic experiences, almost all know (and are often related to) others who have.

RODRÍGUEZ, supra note 42, at 4.

103. López, supra note 5, at 97 ("Latinos are routinely characterized as being of every race.”).

104. Delgado, supra note 33, at 114.

105. Id.

106. See Perea, supra note 27, at 1231-32 ("Whites can ignore our claims to justice, since we are not Black and therefore are not subject to real racism.").

107. Id; see also Richard Delgado, Derrick Bell's Toolkit-Fit to Dismantle That Famous House?, 75 N.Y.U. L. REV. 283, 294 (2000) ("Not only does binary thinking conceal the checkerboard of racial progress and retrenchment, it can hide the way dominant society often casts minority groups against one another, to the detriment of both.”).

108. Wildman, supra note 58 , at 310.

109. Perea, supra note 27, at 1232. 
"have been categorized as irreducibly Other and non-white." ${ }^{110}$ However, the U.S. Census Bureau continues to race Latinos White, but with the restriction that Latinos are the only named White ethnic group. ${ }^{111}$ The Latino identity is not clear because it does not fit within the popular, but incorrect ways of thinking about race and ethnicity. When those false frameworks are applied in the context of school desegregation, Latinos are denied equal opportunity at the very fundamental level of public education.

\section{De Jure School SEgREGATION AND THE LATINO EXPERIENCE}

School segregation, as well as desegregation efforts, have been viewed in a Black-White binary historically. Even when this binary was replaced by a White-Non-White binary, the Latino history of educational segregation was overlooked. The first step in understanding Latinos' contemporary experiences in segregated schools is to review the historical foundations of such segregation. During the early twentieth century, Latinos were raced White in some contexts but segregated from Whites in schools. The first successful case to challenge this segregation in federal court, Mendez v. Westminster, ${ }^{112}$ was decided in 1946. Although Mendez foreshadowed Brown v. Board of Education and played a prominent role in dismantling the system of de facto educational segregation in the United States, Brown did not render the segregation of Latinos unconstitutional.

\section{A. Latino School Segregation: A Historical Primer}

Public elementary education was not widespread in the United States until the mid-nineteenth century. ${ }^{113}$ Public secondary education was not common until the early twentieth century. ${ }^{114}$ School systems often grew as de jure segregated systems; in the South, state or local governments frequently required the segregation of White and Afri-

110. Martinez, supra note 82, at 215.

111. Both the 2000 Census short form and long form listed only ethnic groups of Latino derivation. See United States Census 2000, at http://www.census.gov/dmd/www/pdf/d61a.pdf (last visited Apr. 19, 2001) (short form) (on file with the Duke Law Journal); United States Census 2000, at http://www.census.gov/dmd/www/pdf/d-61b.pdf (last visited Apr. 19, 2001) (long form) (on file with the Duke Law Journal).

112. 64 F. Supp. 544 (1946).

113. Education Week on the Web, Timeline, at http://www.edweek.org/ew/vol-18/20tline.h18 (Jan. 20, 1999) (on file with the Duke Law Journal).

114. Id. 
can American students by law. Professor Mark Tushnet describes the role de jure segregated schools played in maintaining African American subordination, calling segregated schools "a visible and daily demonstration to children as they were growing up that whites did not consider them fit to associate with." ${ }^{, 15}$ De jure segregation also affected Latinos, who, although they were viewed by courts as White for the basic - though not insignificant-purpose of citizenship, were viewed by their communities as categorically Non-White and segregated as such: "Jim Crow, in addition to targeting Blacks, also took aim at Latinos through segregated schools and other public facilities." ${ }^{116}$ It was almost insignificant that Latinos were White for purposes of citizenship, because they were not White for the purposes of enjoying the benefits citizenship should confer, such as education.

Writing in 1920, educator Grace Stanley noted the role the local community played in the creation and perpetuation of an educational system that segregated Latinos:

One of the first demands made from a community in which there is a large Mexican population is for a separate school. The reasons advanced for this demand are generally from a selfish viewpoint of the English-speaking public and are based largely on the theory that the Mexican is a menace to the health and morals of the rest of the community. ${ }^{117}$

In the early twentieth century, the Latino population in the United States was concentrated in the southwest. At this time, the segregation of Latinos in California took the form of "Mexican schools" and "migratory schools." ${ }^{\text {N118 }}$ Not surprisingly, these schools were plagued by "inadequate resources, poor equipment, and unfit building construction," their teachers were paid less than teachers at the White schools, and a promotion for a teacher at a Latino school often consisted of being transferred to the White school. ${ }^{119}$ While these districts were not required by state statute to segregate Latino students, their actions would be characterized under contemporary standards as de

115. MARK V. TUSHNET, MAKING CIVIL Rights LAW: THURGOOD MARSHALl AND THE SUPREME COURT, 1936-1961, at 116 (1994).

116. PEREA, supra note 78, at 304.

117. Charles Wollenburg, All Deliberate SPeed: Segregation and Exclusion IN CALIFORNIA SCHOOLS, 1855-1975, at 111 (1976) (quoting Grace Stanley, Special School for Mexicans, SURVEY, Sept. 15, 1920, at 714).

118. Gilbert G. GonZalez, Chicano Education in the Era of Segregation 103 (1990).

119. Id. at 22 . 
jure segregation because of the districts' prejudice-based intent to educate separately Latino and White students. ${ }^{120}$

In California the establishment of segregated schools occurred "in town after Southern California town" as Latino schools were developed in Pasadena (1913), Mendota (1920), Santa Ana (1920), Ontario (mid-1920s), Riverside (unofficial in 1910, but specially built in 1924), and Los Angeles (by 1933). ${ }^{121}$ The system of segregation was often justified by race-based claims that Latinos simply were not as smart as Whites. In the words of one school superintendent, "Some Mexicans are very bright, but you can't compare their brightest with the average white children. They are an inferior race."122 The common occurrence of Latino school segregation was confirmed in a 1931 survey of school districts with large Latino populations, demonstrating that over $80 \%$ of these districts were officially segregated and many of the remaining $20 \%$ had "unofficial" segregatory practices such as "Americanization" classrooms, ${ }^{123}$ which continued through the 1950s. ${ }^{124}$ Although these programs had the ultimate goal of assimilating Latinos into American society and training them for "appropriate" jobs, those purposes were pursued by isolating Latino students during most of their years as elementary and secondary school students. ${ }^{125}$

While nearly one hundred school desegregation or educationrelated racial discrimination cases were brought in the nineteenth century, ${ }^{126}$ the march toward equality was slow, and the first stuttering steps of progress occurred in state courts. The first known courtordered school desegregation was rendered by a county court in 1931 in Lemon Grove, California. ${ }^{127}$ In 1930, Latinos and Whites attended the Lemon Grove elementary school in nearly equal numbers, with a total enrollment of $169 .{ }^{128}$ The Lemon Grove school board planned to

120. For a discussion of the contemporary standards of intent, see infra note 275 and accompanying text. While there is variation among these standards, the California schools' actions in the early twentieth century meet the requirements of each variation.

121. WOLLENBURG, supra note 117 , at 112.

122. López, supra note 5, at 111-12 (quoting an unidentified school superintendent).

123. WOLLENBURG, supra note 117 , at 116.

124. Id.

125. GonZALEZ, supra note 118, at 22.

126. Caroline Hendrie, In Black and White, EDUC. WK., Mar. 24, 1999, at 31, available at http://www.edweek.com/ew/vol-18/28deseg.h18.

127. Robert R. Alvarez, JR., FAMiLia 154 (1987).

128. Robert R. Alvarez, Jr., The Lemon Grove Incident: The Nation's First Successful School Desegregation Court Case, J. SAN DIEGO HIST., Spring 1986, at 116, 118. 
segregate Latino elementary students by building a new school specifically for Latinos. ${ }^{129}$ When the Latino students were instructed to attend school in this barn-like building, Latino parents first organized a boycott of the separate school. ${ }^{130}$ Then they filed a claim in the Superior Court of San Diego County alleging that the district was unlawfully segregating Latino students. ${ }^{131}$ At the same time, the segregation of Latinos was a topic on the California legislature's agenda, and a bill to permit the segregation of Latinos was defeated, due in part, perhaps, to the Lemon Grove case. ${ }^{132}$ Back in Lemon Grove, the court required the school district to justify its proposed segregation of Latino students, and the district responded with the rationale of "Americanization." ${ }^{133}$ The municipal court ruled in favor of the Latino plaintiffs and prohibited segregation of White and Latino students. ${ }^{134}$ The remedial order followed two days later and made clear that "the laws of the State of California do not authorize or permit the establishment or maintenance of separate schools for the instruction of pupils of Mexican parentage, nationality, and/or descent." ${ }^{135}$ The court considered the state law permitting the segregation of African and Indian students and concluded that because Latinos were not African or Indian, their segregation was not defensible under state law. ${ }^{136}$ The case was not appealed, and it was never mentioned in the minutes of a Lemon Grove school board meeting. ${ }^{137}$

In the early twentieth century, the educational segregation of Latinos was common throughout California and Texas. ${ }^{138}$ The trial court's holding in the Lemon Grove case was an anomaly. A more typical outcome had been reached by a Texas court one year earlier in Independent School District v. Salvatierra. ${ }^{139}$ When Jesus Salvatierra and other local taxpayers in Del Rio, Texas, brought a suit to chal-

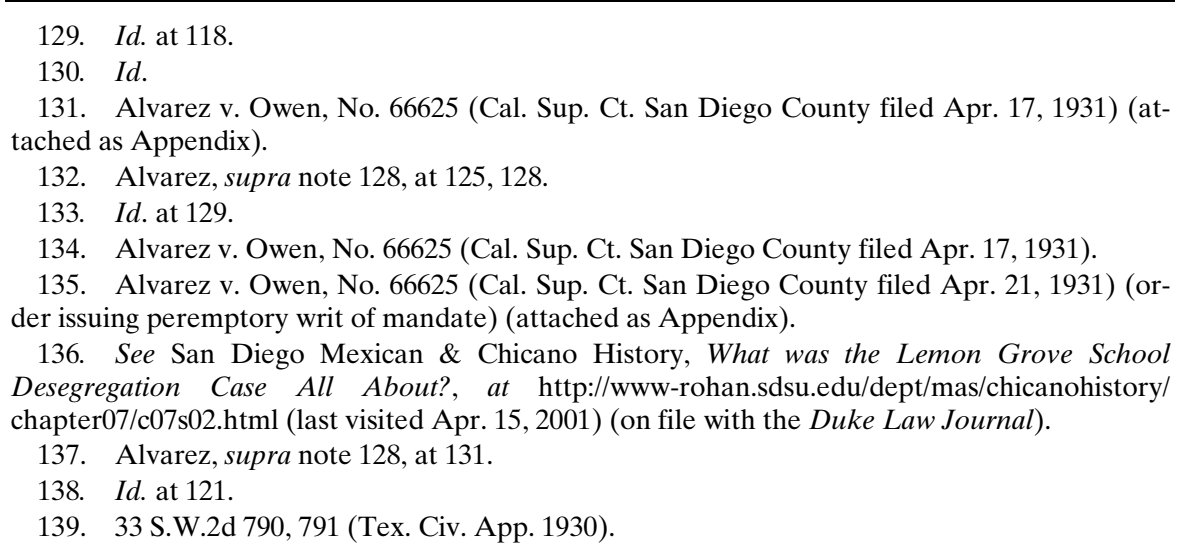


lenge plans to increase the segregation of Latino students, the trial court issued an injunction prohibiting further segregation. ${ }^{140}$ The Texas appellate court reversed, stating that although segregation of Latinos from students of "other white races" ${ }^{141}$ for arbitrary or malicious reasons would not be permitted, the separation was permissible in this case because it was based on acceptable pedagogical reasons. ${ }^{142}$ The appellate court allowed the district to segregate Latino students in early elementary grades for the educational reasons that the migrant schedule affected the length of time Latino students could attend school each year, and, relatedly, that the English language often presented special challenges for Latino students. ${ }^{143}$

This system of widespread Latino segregation in the Southwest persisted until the late 1940 s and early 1950 s, ${ }^{144}$ when community groups, professional educators, and educational psychologists opposed segregation on a large scale. ${ }^{145}$ Their opposition was supported by the weight of the federal courts, which quashed segregation as violative of the Fourteenth Amendment's Equal Protection Clause. The most notable battle was fought in the federal courts in California.

\section{B. Violation of Equal Protection: The Federal Courts Step In}

In 1929, California Attorney General U.S. Webb issued an advisory opinion concluding that the segregation of Latino students could not be defended under California law. ${ }^{146}$ This advisory opinion clearly did not halt the segregation practices in California public schools. In fact, it seems to have had no direct impact at all. Nonetheless, just as Latino parents had prompted Attorney General Webb to issue his ruling, they continued their work as activists throughout the state. In the town of Westminster, California, where the schools were segregated, Gonzalo Mendez and other Latino parents worked with the school board to propose a ballot initiative approving the issuance of

\footnotetext{
140. Id. at 793-94.

141. Id. at 795 .

142. Id.

143. Id. at 791-92, 795 .

144. GonZALEZ, supra note 118 , at 22.

145. WOLLENBURG, supra note 117 , at 118-23. Consider the many groups participating as amici in Brown: the United States, the ACLU, the American Federation of Teachers, the American Jewish Congress, the American Veterans Committee, Inc., the Congress of Industrial Organizations, and the many social scientists who provided the appendix to the appellant's brief. See infra notes 168, 172 and accompanying text.

146. WOLLENBURG, supra note 117 , at 123.
} 
bonds to finance the construction of an integrated school. ${ }^{147}$ However, when the bond proposal failed, board action ceased. ${ }^{148}$ In nearby Santa Ana, William Guzman and other Latino parents attempted to work with their school board to further integrate schools by increasing the size of the transfer program within the district. ${ }^{149}$ This school board, too, was unreceptive to the Latino parents' proposals. Not only did it refuse to increase the transfer program, but it also further restricted the limited number of transfers available. ${ }^{150}$ Mendez and Guzman challenged the decisions of these school boards to perpetuate segregation by becoming two of the five primary plaintiffs in Mendez v. Westminster School District, ${ }^{151}$ the case historian Gilbert Gonzalez describes as "[ $\mathrm{t}]$ he most significant court case affecting the de jure segregation of Mexican children in the Southwest."

The Mendez suit was based upon the Fourteenth Amendment to the United States Constitution, and the claim was filed in a California federal district court in $1945 .^{153}$ While the school districts claimed to segregate students for the purpose of language instruction, the district court concluded that the student assignment process was sometimes completed on the basis of the student's name alone, with no knowledge of the student's English language proficiency. ${ }^{154}$ Latino students in California never were segregated at the demand of a state statute, but the district court concluded in Mendez that because the practice of segregating Latinos in public schools violated the state and federal constitutions, ${ }^{155}$ the plaintiffs were entitled to injunctive relief so the defendant school districts could no longer segregate Latino students. ${ }^{156}$ Specifically, the court held:

"The equal protection of the laws" pertaining to the public school system in California is not provided by furnishing in separate schools the same technical facilities, text books and courses of instruction to children of Mexican ancestry that are available to the other public school children regardless of their ancestry. A paramount requisite

\footnotetext{
147. Id. at 125 .

148. Id.

149. Id.

150. Id.

151. 64 F. Supp. 544 (S.D. Cal. 1946).

152. GONZALEZ, supra note 118 , at 28 .

153. WOLLENBURG, supra note 117 , at 108 .

154. Mendez, 64 F. Supp. at 550.

155. Id. at 549.

156. Id. at 551.
} 
in the American system of public education is social equality. It must be open to all children by unified school association regardless of lineage. ${ }^{157}$

Importantly, the district court discussed a state statute under which schools could legally segregate students. ${ }^{158}$ This statute was the successor to the statute reviewed in the Lemon Grove case and was titled "Schools for Indian children, and children of Chinese, Japanese, or Mongolian parentage." Grove case, the federal district court concluded that the statute was "not pertinent to this action" 160 because, as the court had previously noted, "[i]t is conceded by all parties that there is no question of race discrimination in this action." ${ }^{\text {"161 }}$ While the plaintiff class was described as those of Mexican "extraction," "descent," or "ancestry,"162 their race was not disputed because the court presumed that the Latino plaintiffs were racially White. ${ }^{163}$ The NAACP filed a cautious amicus brief in Mendez at the appellate level, introducing social science evidence about the general harm of segregation. ${ }^{164}$ Another amicus brief filed by lawyer and historian Carey McWilliams focused on the specific harm of segregation in the educational context. ${ }^{165}$ The Ninth Circuit Court of Appeals affirmed the district court's decision, but the social science evidence was not part of its reported decision. ${ }^{166}$

An unsigned student note in the Yale Law Journal one year after Mendez noted prophetically that Mendez "has questioned the basic assumption of the Plessy case... . Modern sociological and psychological studies lend much support to the District Court's views. A dual school system, even if 'equal facilities' were even in fact provided,

\footnotetext{
157. Id. at 549 .

158. Id. at 548 n.5.

159. Id.

160. Id. at 548 .

161. Id. at 546 .

162. Id.

163. GONZALEZ, supra note 118 , at 152 .

164. Delgado, supra note 107, at 304.

165. Id. at 304-05.

166. The Ninth Circuit concluded:

By enforcing the segregation of school children of Mexican descent against their will and contrary to the laws of California, respondents have violated the federal law as provided in the Fourteenth Amendment to the Federal Constitution by depriving them of liberty and property without due process of law and by denying to them the equal protection of the laws.

Westminster Sch. Dist. v. Mendez, 161 F.2d 774, 781 (9th Cir. 1947).
} 
does imply social inferiority." 167 This comment is particularly insightful because neither court in Mendez took the step that Brown later did of connecting social science studies about segregation to the harm that must be redressed by a court's remedial order. This social science evidence became well known in academic circles a decade after Men$d e z$ and was attached as an appendix to appellants' briefs in Brown. ${ }^{168}$ Writing many years after both Mendez and Brown, historian Charles Wollenburg's words reminded readers of the context in which Mendez must be understood: Mendez "was part of a process which stripped away the formal structure of legalized segregation and exposed the underlying conditions of racism and reaction that divide the American people and plague their consciences." 169

The next major step towards achieving equal educational opportunity for all students - and the one known by most Americans today-was the landmark 1954 decision Brown v. Board of Education. ${ }^{170}$ While Brown declared in Chief Justice Earl Warren's now famous words that "[s]eparate educational facilities are inherently unequal, ${ }^{, 171}$ it omitted any reference to Mendez or, indeed, to Latino segregation at all. A distinction can be drawn that the Brown decision was premised on racial segregation, which had not been directly at issue in Mendez, according to the district court. Factual distinctions aside, the reasoning in Mendez not only was rare in American jurisprudence, it also was quite applicable to Brown. Inequality based on separation is unconstitutional when the separation is premised on a fallacious assumption of difference. Despite this analytical similarity, neither the parties nor amici in Brown cited Mendez in their briefs to the Supreme Court. ${ }^{172}$ The fact that the Court did not mention Men-

167. Note, Segregation in Public Schools-A Violation of "Equal Protection of the Laws," 56 YALE L.J. 1059, 1060 (1947).

168. See 49 LANDMARK Briefs AND ARguments of the Supreme Court of the United States: Constitutional Law 41-66 (Philip B. Kurland \& Gerhard Casper eds., 1975) [hereinafter LANDMARK BRIEFS] (reprinting the statement authored by thirty-two social scientists in various disciplines and filed as an appendix to the appellants' brief in Brown).

169. WOLLENBURG, supra note 117, at 135.

170. 347 U.S. 483 (1954); see also David J. Garrow, The Supreme Court's Pursuit of Equality and Liberty and the Burdens of History, in REDEFINING EQUALITY 205, 205 (Neal Devins \& Davison M. Douglas eds., 1998) ("The Supreme Court's decision in Brown v. Board of Education is commonly regarded as the signal event in the modern quest for racial equality.") (citation omitted).

171. 347 U.S. at 495.

172. See 49 LANDMARK BRIEFS, supra note 168, at 24-26 (reprinting the table of cases in the appellants' brief before the initial oral argument); $i d$. at 68-69 (reprinting the table of cases in the appellees' brief before the initial oral argument); $i d$. at 114-15 (reprinting the table of cases in the United States' amicus brief before the initial oral argument); id. at 151-53 (reprinting the 
$d e z$ is especially surprising in light of Chief Justice Warren's personal experience:

[T] he Mendez decision ... led to California's repeal of its school segregation statutes. Then Governor Earl Warren signed legislation repealing California's segregation statutes on June 14, 1947. This was, of course, the same Earl Warren who, as Chief Justice of the United States, would later pen the opinions in Brown v. Board of Education and Hernandez v. Texas.

The Court decided Brown a mere twelve days after it announced its opinion in Hernandez v. Texas, ${ }^{174}$ where the Court declared Latinos to be a protected class in the context of jury eligibility. ${ }^{175}$ Interestingly, Latino school segregation was noted as an indicator of Latinos' socially created "difference" in Hernandez. ${ }^{176}$ Therefore, the Court was considering the issues of Latino identity and of school desegregation concurrently. Because the Court carefully dodged the question of Latinos' racial identity in Hernandez, though, it is not surprising that the Court did not address the question of Latino school segregation in Brown. After all, Brown occurred within the familiar Black-White binary.

table of cases in the ACLU's amicus brief before the initial oral argument); id. at 197 (reprinting the table of cases in the American Federation of Teachers's amicus brief before the initial oral argument); id. at 217-18 (reprinting the table of cases in the American Jewish Congress's amicus brief before the initial oral argument); $i d$. at 242-43 (reprinting the table of cases in the American Veterans Committee's, Inc., amicus brief before the initial oral argument); id. at 263-75 (reprinting the Congress of Industrial Organizations's amicus brief before the initial oral argument); $i d$. at 488-92 (reprinting the table of cases in the appellants' brief prior to reargument); $i d$. at 750 (reprinting the table of cases in the Board of Education's brief prior to reargument); $i d$. at 761 (reprinting the table of cases in the state of Kansas's brief prior to reargument); id. at 855-58 (reprinting the table of cases in the United States' amicus brief prior to reargument); 49A LANDMARK BRIEFS, supra note 168, at 400 (reprinting the table of cases in the American Federation of Teachers's amicus brief prior to reargument); $i d$. at 428-29 (reprinting the table of cases in the American Veterans Committee's amicus brief prior to reargument).

173. Perea, supra note 27, at 1247 (citations omitted). Though his role in uniting the Court in Brown is commendable, Chief Justice Warren was not a civil rights hero for all groups. His role in confining Japanese Americans to internment camps while serving as California's Attorney General comes to mind. See Ed Cray, Chief Justice: A Biography of EARL WARren 120-23 (1997) (describing Warren's leading role in the internment of Japanese Americans during World War II).

174. 347 U.S. 475 (1954).

175. Id. at $476-80$.

176. Id. at 479 . 


\section{The WHITE-Non-White PARADIGM IN SCHOOL DESEGREGATION}

The Black-White binary of the past forced Latinos into one of two categories when they fit into neither. The frequent racing of Latinos as White by the courts did not lead to similar experiences for Whites and Latinos. In 1973, the Supreme Court's endorsement of the White-Non-White paradigm and designation of Latinos as NonWhite in Keyes v. School District No. $1^{177}$ would seem to have benefited Latinos. Instead, this new framework merely continued to keep Latinos invisible. The inequality resulting from Latinos' invisibility will continue as long as racial and ethnic groups are defined by reference to the normalized standard of White.

\section{A. The Supreme Court Speaks}

While Brown introduced the Black-White paradigm into school desegregation litigation, Keyes v. School District No. 1, challenging school segregation in Denver, introduced the White-Non-White paradigm into Supreme Court jurisprudence nearly twenty years later. ${ }^{178}$ Keyes has been hailed as the decision that brought school desegregation to the North. Notably, it was the first Supreme Court case to hold that statutory segregation was not required for a district to be found liable for de jure segregation. ${ }^{179}$ Thus, Keyes was the basis for a new wave of litigation. However, Keyes almost never is recognized for its significant holding that Latino students should be classified with African American students as Non-White for purposes of school desegregation. $^{180}$

For sixteen years, no court interpreted Brown to prohibit the segregation of Latino students. Then, in a span of three months in 1970, two federal district courts held that Latinos should be considered distinct from Whites in the context of school desegregation. ${ }^{181}$ In

\footnotetext{
177. 413 U.S. 189 (1973).

178. Id.

179. Id. at 201.

180. For example, this aspect of Keyes is omitted from notable Constitutional Law casebooks. See infra notes $288-92$ and accompanying text.

181. See Cisneros v. Corpus Christi Indep. Sch. Dist., 324 F. Supp. 599, 606 (S.D. Tex. 1970) (finding that "Mexican-American students are an identifiable, ethnic-minority class sufficient to bring them within the protection of Brown"); Keyes v. Sch. Dist. No. 1, 313 F. Supp. 61, 69 (D. Colo. 1970) ("It would seem that to the extent that Hispanos, as a group, are isolated in concentrated numbers, a school in which this has occurred is to be regarded as a segregated school ....") . The district court's opinion in Keyes was reported in two parts. See Keyes v. Sch.
} 
the Corpus Christi, Texas, school district, nearly half the students were Latino, nearly half were White, and approximately $4 \%$ were African American. ${ }^{182}$ In the case arising out of this school system, Cisneros v. Corpus Christi Independent School District, the district court held that Brown protected Latino students ${ }^{183}$ and that the segregation of both Non-White groups resulted in a constitutionally impermissible dual school system. ${ }^{184}$ The Fifth Circuit affirmed two years later, correctly anticipating the Court's decision in Keyes. ${ }^{185}$

Similarly, in Denver the demographic composition of the public school system in 1968 did not fit the Black-White binary: approximately $71 \%$ of the students were White, $13 \%$ were African American, and $16 \%$ were Latino. ${ }^{186}$ Aware of this problem, the school board adopted resolutions to desegregate the Denver schools by changing attendance boundaries. ${ }^{187}$ Before the resolutions were fully implemented, however, a newly elected school board rescinded the resolutions and implemented a voluntary exchange program. ${ }^{188}$ In the school desegregation suit filed in 1968, Keyes v. School District No. 1, the district court found the school system liable for intentional segregation and entered a remedial order. ${ }^{189}$ The district court considered Latinos Non-White ${ }^{190}$ and concluded that a Denver school with $70-75 \%$ Latino or African American students would be considered impermissibly racially identifiable. ${ }^{191}$ It distinguished between Latino and African American students ${ }^{192}$ and noted the "desirability (even though it is not constitutionally mandated) of having both Negroes and Hispanos in

Dist. No. 1, 313 F. Supp. 61, 69 (D. Colo. 1970) (making findings of fact and law) and Keyes v. School Dist. No. 1, 313 F. Supp. 90 (D. Colo. 1970) (prescribing a remedy).

182. Cisneros, 324 F. Supp. at 611 n.37.

183. Id. at 606.

184. Id. at 620 . The district court also found that the segregation was de jure even though it resulted not from a statute, but from a series of actions taken by the district. Id. at 617-20.

185. The Fifth Circuit affirmed both the finding of unconstitutional segregation and the remedy ordered, with leave to amend the remedy "as the practicalities of the situation require in order to avoid undue hardships or burdens on the School Board." Cisneros v. Corpus Christi Indep. Sch. Dist., 467 F.2d 142, 167 (5th Cir. 1972).

186. Keyes v. Sch. Dist. No. 1, 445 F.2d 990, 996 n.1 (10th Cir. 1971).

187. Id. at $996-97$

188. Id.

189. Keyes v. Sch. Dist. No. 1, 313 F. Supp. 61, 83-85 (D. Colo. 1970) (holding the district liable and beginning the discussion of a remedy); Keyes v. Sch. Dist. No. 1, 313 F. Supp. 90, 9199 (discussing the plaintiffs' and defendants' proposals and instituting a remedial order).

190. Keyes v. Sch. Dist. No. 1, 313 F. Supp. 61, 69 (D. Colo. 1970).

191. Id. at 77 .

192. Id. at 69 . 
the desegregated schools on as close to an equal basis as possible." ${ }^{193}$ The Tenth Circuit affirmed in part, reversed in part, and remanded the case, but it did not question the designation of Latinos as NonWhite. ${ }^{194}$

When Keyes was argued in the Supreme Court one year later (in 1972), $66 \%$ of students in the Denver school system were White, $14 \%$ were African American, and 20\% were Latino. ${ }^{195}$ The Supreme Court held in part that on remand the district court in Keyes should consider African Americans and Latinos to be part of the same group for purposes of school desegregation. ${ }^{196}$ Denver schools that had $70-75 \% \mathrm{La}-$ tino students, African American students, or a combination of Latino and African American students were held to be impermissibly racially identifiable. ${ }^{197}$ The Court acknowledged its decision in Hernandez v. Texas $^{198}$ that Latinos can constitute a constitutionally protected class but relied upon the report of the United States Commission on Civil Rights to conclude that "though of different origins, Negroes and Hispanos in Denver suffer identical discrimination in treatment when compared with the treatment afforded Anglo students." Court announced no reason to distinguish between Latino and African American students.

In Keyes, the Supreme Court collapsed the Latino and African American narratives of segregation and discrimination by making Latinos, who had been raced White by courts (and would continue to be raced White by the U.S. Census Bureau), Non-White for purposes of school desegregation. These new lines of group identification are easily recognizable in the terms "minority" and "majority,"-meant to be racial and ethnic descriptions-which pervade not only contemporary school desegregation litigation, but also American popular culture. The employment of the White-Non-White paradigm through the use of "minority" and "majority" classifications leads to a shallow understanding of the range of educational experiences among Non-

193. Keyes v. Sch. Dist. No. 1, 313 F. Supp. 90, 100 (D. Colo. 1970).

194. Keyes v. Sch. Dist. No. 1, 445 F. 2d 990, 1007 (10th Cir. 1971).

195. Keyes v. Sch. Dist. No. 1., 413 U.S. 189, 195 (1973).

196. Id. at 197-98.

197. Id.

198. 347 U.S. 475 (1954).

199. Keyes, 413 U.S. at 197-98. 
White students. By denying these differences, courts do not allow African Americans and Latinos to benefit similarly from Brown. ${ }^{200}$

The numerous districts found liable in school desegregation cases filed in the 1970s and 1980s now have been subject to the oversight of federal district courts for two or more decades, and many districts are seeking declarations of unitary status. ${ }^{201} \mathrm{~A}$ unitary status decree involves a finding that the school district in question is no longer operating an impermissible de jure segregated dual system and therefore can be released from the oversight of the federal courts. ${ }^{202}$

The Court's language in its unitary status decisions echoes the White-Non-White paradigm articulated in Keyes. The Court continued to take the lead in elaborating the White-Non-White paradigm in Jenkins III, ${ }^{203}$ using the term "minority" ${ }^{204}$ to describe Non-White ra-

200. For a discussion of the different educational experiences of Latinos and African Americans, see infra notes $212-30$ and accompanying text. The differences in the specific context of school desegregation are discussed infra at notes 221-29 and accompanying text.

201. Wendy Parker, The Future of School Desegregation, 94 Nw. U. L. REV. 1157, 1157-58 (2000).

202. Ultimately, the determination of unitary status is based upon an evaluation of the six factors articulated by the Supreme Court in 1968 in Green v. County School Board: student attendance patterns, faculty assignments, staff assignments, transportation, extra-curricular activities, and school facilities. 391 U.S. 430, 435 (1968). In 1992, the Court in Freeman v. Pitts modified Green by allowing federal courts "to relinquish supervision and control of school districts in incremental stages, before full compliance [had been] achieved in every area of school operations." 503 U.S. 467, 490-91 (1992).

The Freeman test requires that federal courts apply the following three criteria to each of the Green factors: compliance in the specific area in which the school district is seeking release, a determination of whether judicial control is necessary to achieve the remainder of the remedial order, and the school district's good faith effort to comply with the remedial order. Id. at 491. The district's good faith effort (a criterion introduced one year prior to Freeman in Board of Education v. Dowell, 498 U.S. 237, 249-50 (1991)), is not defeated by a lack of achievement of the desired results; good faith compliance may exist where "vestiges of past discrimination have been eliminated to the extent practicable." Freeman, 503 U.S. at 492. Thus, a district can reassign its teachers and staff in a racially equitable manner (considering the race of the teachers, the race of the students, and teachers' and staff members' levels of experience) and be released from court control about matters of teacher and staff assignments, even though the district's processes of student assignment may continue to be within the jurisdiction of the court. Id.

A school district's incentives to obtain a "unitary status" decree will be diminished if the district can be declared "partially unitary." If a district can be declared "partially unitary," the district can significantly reduce the degree of court supervision (albeit not completely) with something less than total compliance.

203. Missouri v. Jenkins, 515 U.S. 70 (1995).

204. Id. at $87,94 \mathrm{nn} .6,101-02 \& 119$. 
cial and ethnic groups. ${ }^{205}$ Rather than the term "majority," the Jenkins III Court used "non-minority." "206 These terms-and thus this paradigm-have saturated federal district courts. When rendering decisions on motions for unitary status as recently as the past two years, federal district judges have measured desegregation in terms of "minority" and "majority" populations in Topeka, Kansas; ${ }^{207}$ Autauga County, Alabama; ${ }^{208}$ Woodland Hills, Pennsylvania, ${ }^{209}$ Yonkers, New York; ${ }^{210}$ and Benton Harbor, Michigan. ${ }^{211}$ The White-Non-White paradigm is alive and well in federal district courts across the country.

\section{B. Why Difference Matters: The Contemporary Latino Educational Experience}

While Latinos and African Americans share the common bond of being consistently viewed as other-than-White in the context of school desegregation litigation, significant differences between the two groups remain. The differences start on a fundamental level: while African Americans are presumed to have United States citizenship and to have been socialized as Americans, this presumption does not exist for non-African American Non-Whites, including Latinos. ${ }^{212}$ An additional presumption of "foreignness" layered upon Latinos' group identity relates to language. ${ }^{213}$ Because approximately one-third

205. Id. at 76, 78, 142-44. Translating this term into the White-Non-White paradigm results in a term reminiscent of an awkward, though technically accurate foreign language translation: "non-minority" becomes "Non-Non-White."

206. Id.

207. Brown v. Unified Sch. Dist. No. 501, 56 F. Supp. 2d 1212-14 (D. Kan. 1999) (holding that the district had satisfied the demands of the remedy and was therefore declared unitary).

208. Lee v. Autauga County Bd. of Educ., 59 F. Supp. 1199, 1201-02 n.12, 1208 \& 1210

(M.D. Ala. 1999) (denying the defendant's motion for unitary status).

209. Hoots v. Pennsylvania, 118 F. Supp. 2d 577, 580-81, 584, 586 (W.D. Pa. 2000) (denying the defendant's motion for unitary status).

210. United States v. Yonkers Bd. of Educ., 123 F. Supp. 2d 694, 696-97 (S.D.N.Y. 2000) (denying a request for unitary status and indicating that a modified remedial order would follow). Interestingly, the court in Yonkers declared that "minority" students for the purposes of this case are Latino and African American students, while "majority" students are White and Asian American students. Id. at 706.

211. See Berry v. Sch. Dist., 56 F. Supp. 2d 866, 876 (W.D. Mich. 1999) (discussing the obligations of a charter school in a school district currently under court order and suggesting that the district could be granted unitary status in 2002).

212. Neil Gotanda, Asian American Rights and the "Miss Saigon Syndrome," in AsIAN AMERICANS AND THE SUPREME COURT 1087, 1096 (Hyung-chan Kim ed., 1992).

213. This presumption is illustrated by my own understanding of race and ethnicity as a four-year-old child. One Saturday morning, as I accompanied my father on weekend errands, we stopped to talk with one of his friends (accompanied by his own five-year-old daughter) who was coming out of my father's barber shop just as we were going in. My father's friend was 
of all Latinos in the United States tend to be immigrants, ${ }^{214}$ more Latinos (than Whites or African Americans) have a need to improve their English language skills. The recent "English only" movement, echoed in the attacks on bilingual education, reveals hostility to Spanish speakers and emphasizes the presumption of foreignness. ${ }^{215}$ Latinos recognize these many layers of assumptions when they are manifested in the form of discrimination against Latinos as an identifiable group. ${ }^{216}$

Latinos' socioeconomic inequality vis-à-vis Whites and African Americans is echoed in the educational realm. Latinos have the highest high school drop-out rates: in 1998, 30\% (1.5 million) of Latinos aged sixteen to twenty-four had dropped out of school, compared to only $8 \%$ of Whites and $14 \%$ of African Americans the same age. ${ }^{217}$ Of the dropouts, $40 \%$ of the Latinos had less than a ninth-grade education when they left school, compared to $13 \%$ of Whites and $11 \%$ of African Americans. ${ }^{218}$ Although the number of Latinos attending a college or university has increased dramatically over the past twenty

White, and the five year-old that accompanied him was his adopted Korean American daughter. When my father and I entered the barber shop after our brief pause for conversation, I offered the perplexed observation that the other little girl "has Chinese eyes, but she talks right." Somehow, I had the discretion (thankfully) not to make this statement during our conversation. This girl was probably the first Non-White person with whom I substantively interacted. My church and preschool were essentially all-White. It is likely, therefore, that my assumptions were gleaned from television and from the media more generally.

214. Mendieta, supra note 57, at 127.

215. For example, a naturalized Latina citizen was ordered by a court in 1995 to speak English to her young daughter because to do otherwise is, in the court's words, "abusing that child." Diane Jennings, Judge Orders Amarillo Mother to Speak English to Daughter: Not Doing So Is “Abusing" Child, He Rules in Custody Case, Dallas Morning News, Aug. 29, 1995, at 1A.

216. See RODRÍGUEZ, supra note 42, at 20 ("In one of the largest and most comprehensive surveys of Latinos, 80 percent of Mexicans, 74 percent of Puerto Ricans, and 47 percent of $\mathrm{Cu}$ bans reported 'a lot' or 'some' discrimination against their own group, a general perception that appeared unrelated to skin color."); see also Yzaguirre \& Kamasaki, supra note 53, at 1-2 (providing an overview of the "scope and degree of discrimination against Hispanic Americans with respect to employment and housing").

217. PRESIDENT'S AdVISORY COMM'N ON EDUC. EXCELlENCE FOR HisPANIC AMS., CREATING THE WiLl: HisPanics ACHIEVING EdUCATIONAl EXCELlENCE 24 (2000) [hereinafter CREATING THE WILL]. These figures did not change between 1994 and 1998. See DAVIS, supra note 5, at 111 (reporting similar figures for 1994 of a 30\% dropout rate among Latinos, $8 \%$ among Whites, and 13\% among African Americans).

218. White House Initiative on Educ. Excellence for Hispanic Ams., State of Education for Hispanic Americans, in Our Nation on the Fault Line: Hispanic American Education, at http:// www.ed.gov/pubs/FaultLine/state.html (Sept. 1996) (on file with the Duke Law Journal). 
years, ${ }^{219}$ Latinos still attend a college or university in lower proportions than Whites or African Americans. ${ }^{220}$

The disparities reach beyond the realm of attendance and graduation rates. Social science research has rarely focused on the contemporary educational segregation of Latinos, but the limited research in this area suggests that Latinos suffer disproportionately from school segregation. ${ }^{221}$ The President's Advisory Commission on Educational Excellence for Hispanic Americans has reported that Latinos are "more segregated" and "more concentrated in high-poverty schools than any other group of students."222 Latinos' concentration in high-poverty schools has increased at an alarming rate: between 1988 and 1993, the likelihood that a Latino student would be in a high poverty school increased from $14 \%$ to $40 \%{ }^{223}$ Comparable rates for Whites increased from $7 \%$ to $8 \%$, and African Americans' likelihood increased from $11 \%$ to $25 \%{ }^{224}$ Latino school segregation has "remained in an unbroken pattern of increasing segregation" since the $1960 \mathrm{~s},{ }^{225}$ and it dramatically increased in the 1970 s and $1980 \mathrm{~s} .{ }^{226}$

Although segregated Latino schools often share characteristics of segregated African American schools (poorer students than in White or integrated schools, lower levels of competition, significantly higher dropout rates, and low scores on college entrance exams by those who

219. See Daren Fonda, The Male Minority, TIME, Dec. 11, 2000, at 58-59 (noting that between 1977 and 1997, the percentage of Latino women entering college rose by $327 \%$ and the percentage of Latino men entering college rose by $152 \%$; comparable figures for White women were a $34 \%$ increase, for White men an $8 \%$ decrease, for African American women an $81 \%$ increase, and for African American men a 33\% increase).

220. Mendieta, supra note 52, at 45 .

221. See Gary Orfield, School Desegregation After Two Generations: Race, Schools, and Opportunity in Urban Society, in RACE IN AMERICA: THE STRUGGLE FOR EQUALITY 234, 255 (Herbert Hill \& James E. Jones, Jr. eds., 1993) ("It is hard to understand the implications of what is happening to the group that is becoming the nation's largest minority; little serious research has been conducted.").

222. CREATING THE WILL, supra note 217, at 23; see also Gary Orfield, The Growth of Segregation: African Americans, Latinos, and Unequal Education, in DISMANTLING DESEGREGATION: THE QUIET REVERSAL OF BROWN V. BOARD OF EDUCATION 53, 60 (Gary Orfield \& Susan E. Eaton eds., 1996) [hereinafter DisMANTLING DESEGREGATION] (discussing the concentration of Latinos in high-poverty schools). Professor Gary Orfield of the Harvard Civil Rights Project has concluded that the rate of Latino segregation varies in different regions of the United States, but occurs at a lower rate in the Midwest. Id. at 58.

223. Susan E. Eaton, Slipping Toward Segregation: Local Control and Eroding Desegregation in Montgomery County, in DisMANTLING DESEGREGATION, supra note 222, at 207, 217.

224. Id.

225. Orfield, supra note 222 , at 53.

226. Id. at 59-60. 
do finish) ${ }^{227}$ recent school desegregation litigation initiated by African Americans has not necessarily been helpful to Latinos. ${ }^{228}$ Professor of Education and Social Policy Gary Orfield has recognized what most courts do not: a trial and a resulting remedial order that treat African Americans and Latinos the same do not sufficiently allow for the dramatic differences in the contemporary experiences of Latinos and African Americans. While the characterization of Latinos as NonWhite demonstrates a need for their integration with White students, such classification results in the tangible harm of increased segregation of Latinos, and the denial of fundamental differences, such as English language speaking ability. These results relate directly to the concentration of Latinos in high-poverty schools, and also likely relate to Latinos' high drop-out rates and thus economic inequality. Quantifying this harm, the President's Advisory Commission on Educational Excellence for Hispanic Americans stated, "[a] social disaster is in the making. The continued denial of the tools of excellence will exact a high economic toll on individual Hispanics, the Hispanic community, and the nation as a whole."229

When the African American and Latino stories are collapsed, both are disadvantaged in intangible ways. Each group is denied its own history and the recognition of its unique present experiences when the characteristic that becomes most important is that the group is Non-White-that it has been discriminated against by Whites historically and that it is less privileged than Whites currently. These generalizations are technically accurate but dangerously overbroad. Because of their overbreadth, the claims are especially damaging to Latinos. While the African American civil rights struggle is a wellknown part of our history, the Latino struggle is not. Characterizing Latinos as merely Non-White for historical purposes can lead to the assumption that Latinos never suffered invidious discrimination because, in the United States, Whites did not systematically enslave Latinos. Similarly, to conclude that Latinos were not discriminated against because they were considered legally White by courts in the $1870 \mathrm{~s}^{230}$ would be akin to arguing that Latinos are not presently discriminated against because the United States Census also classifies

227. Orfield, supra note 222, at 58; Orfield, supra note 221, at 255-56.

228. Orfield, supra note 221, at 256.

229. White House Initiative on Educ. Excellence for Hispanic Ams., supra note 69.

230. See supra notes 80-82 and accompanying text. 
them as racially White. These interpretations based on the WhiteNon-White paradigm threaten Latinos' pursuit of equality by assuming the existence of a level playing field where none exists.

\section{Recognition of the White Norm}

Defining Latinos and African Americans as Non-White has some benefits. For instance, it brings repeated emphasis to the usually invisible standards of whiteness and White privilege. Systemic privilege results from one group being considered the norm and other groups being considered deviants from that norm. In the words of Professor Stephanie Wildman and her co-authors, "privilege is not visible to the holder of the privilege; privilege appears as part of the normal fabric of daily life, not as something special." 231 Feminist scholars have exposed male privilege: the fact that women are disadvantaged because of their sex and are aware of their sex as a potentially negative attribute, even though women compose half the nation's population. Similarly, queer theorists have delineated heterosexual privilege: the fact that heterosexuals do not think about their sexuality, while homosexuals and bisexuals are continually aware of their difference from the norm and are frequently discriminated against on that basis. In both of these situations, the privileged group is usually unaware of its privilege and does not think of itself as being stigmatized because of how society classifies it. The norm of White privilege functions in a similar manner.

The hallmark of White privilege is Whites' ability to go through their lives without thinking that the way they relate to the world and the way the world relates to them is influenced by their race. ${ }^{232}$ Whites' ability to disregard their race-and thus to think of whiteness as the normative model-is a product of Whites' dominance, just as men's ability to disregard their sex is a product of male dominance

231. Stephanie M. Wildman, Privilege in the Workplace: The Missing Element in Antidiscrimination Law, in PRIVIlege ReVealed: How InVISIBle PrefERENCE Undermines AMERICA 25, 27 (Stephanie M. Wildman ed., 1996).

232. Professor Barbara Flagg elaborates on the invisibility of whiteness to Whites: "[I]n this society, ... the white person has an everyday option not to think of herself in racial terms at all. In fact, whites appear to pursue that option so habitually that it may be a defining characteristic of whiteness: to be white is not to think about it." Barbara J. Flagg, "Was Blind, But Now I See": White Race Consciousness and the Requirement of Discriminatory Intent, 91 MICH. L. REV. 953, 969 (1993); see also Bonnie Kae Grover, Growing Up White in America?, reprinted in CRITICAL WHITE STUDIES, supra note 28, at 34, 34 ("White is transparent. That's the point of being the dominant race. Sure, the whiteness is there, but you never think of it. If you're white, you never have to think of it."). 
and heterosexuals' ability to disregard their sexuality is a product of heterosexual dominance. ${ }^{233}$ As Professor Barbara Flagg notes, "[t]he imposition of transparently white norms is a unique form of unconscious discrimination. ${ }^{\text {234 }}$ Indeed, it is unique precisely because the standard has been so normalized as to have become unconscious. In an attempt to make White privilege visible, Peggy McIntosh, the associate director of the Wellesley College Center for Research on Women, reports many specific ways in which White privilege functions. The examples she highlights include Whites' comparative ease finding housing, ability to shop without being followed because of race-based suspicions of shoplifting, a general emphasis on historical contributions of Whites, never being asked to speak for all Whites, advocating racial equality without risk, and using "flesh" color bandages and cosmetics that are closest in color to White skin. ${ }^{235}$ Professor Stephanie Wildman has explored this issue further, specifically seeking to understand the benefits of American White privilege vis-àvis Latinos. ${ }^{236}$ She gives more examples: others are not surprised when Whites speak fluent English; they assume Whites were born in the United States; and they pronounce Whites' names properly, or, if there is a question about the pronunciation, will politely make such an inquiry. ${ }^{237}$

White privilege is reinforced when racial and ethnic groups are conceptualized not as White, African American, Latino, Asian American, Native American, etc., but instead as White or Non-White. Acknowledgement of differences among groups disappears in a White-Non-White paradigm, because instead of allowing racial or ethnic groups to identify themselves by what they are, ${ }^{238}$ all Non-

233. Trina Grillo \& Stephanie M. Wildman, Obscuring the Importance of Race: The Implication of Making Comparisons Between Racism and Sexism (or other-isms), 1991 DUKE L.J. 397, 405 (discussing how majoritarianism made whiteness the normative model).

234. Flagg, supra note 232, at 959.

235. Peggy McIntosh, White Privilege and Male Privilege: A Personal Account of Coming to See Correspondences Through Work in Women's Studies, in POWER, PRIVILEGE, AND THE LAW: A Civil Rights READER 22, 25-27 (Leslie Bender \& Daan Braveman eds., 1995).

236. Wildman, supra note 58, at 313-14 (basing her list of privileges on the McIntosh model). 237. Id.

238. Admittedly, it is different for White groups to do this, aside from describing White culture as American popular culture. In Noel Ignatiev's words, "there is no 'white' culture-unless you mean Wonder bread and television game shows. Whiteness is nothing but an expression of race privilege." Treason to Whiteness Is Loyalty to Humanity: An Interview with Noel Ignatiev of Race Traitor Magazine, THE BLAST!, June-July 1994, reprinted in PEREA, supra note 78, at 490. While differences exist between White subgroups who trace their heritage to include Eastern European Jews or those who trace their lineage to the Scotch-Irish (and these individual groups 
White groups are explicitly identified by what they are not, and only by reference to whiteness. Although aspects of a specific Non-White group might be easier to identify than "White culture," this occurs because White culture is mainstream culture. The culture of a specific Non-White group appears distinctive because it deviates from the norm. Professor Martha Mahoney notes that a term such as "racially identifiable" in the context of housing and urban development generally refers "to locations that are racially identifiably black." ${ }^{239}$ The same is true in the context of education: racially identifiable means racially identifiably Non-White.

The White-Non-White paradigm reinforces the power dynamic of the acted and the acted upon, of presence and absence, of the defining and the defined. The power that Whites receive from their unearned privilege in the White-Non-White duality "is, in fact, permission to escape [the debate of race] or to dominate." ${ }^{240}$ When federal courts reinforce this dynamic in the name of school desegregation, they perpetuate the normalized, mainstream practices and institutions that reinforce racial inequality. It is often these practices and institutions that are most damaging in terms of perpetuating oppression because they are not usually questioned. They are conceptualized as just normal. ${ }^{241}$

In contemporary school desegregation jurisprudence, Whites are normalized, and all Non-Whites are collapsed into the category of "other." Like African Americans, Latinos have been the victims of state-sanctioned educational segregation, ${ }^{242}$ but if courts gave attention to the present differences between African Americans and Latinos, courts' remedial orders would likely be structured differently. As will be discussed below, the recognition of Latinos and African Americans as distinct groups that continue to suffer different harms is easily within reach.

have their own culture) the various White subgroups share the most important feature of having the social privilege and power of Whiteness.

239. Mahoney, supra note 22, at 1666.

240. McIntosh, supra note 235, at 30.

241. Describing the danger of normalized discrimination, Ignatiev argues, "The color line is not the work of the relatively small number of hard-core 'racists'; target not them but the mainstream institutions that reproduce it." Noel Ignatiev, How to Be a Race Traitor, reprinted in PEREA, supra note 78, at 493.

242. See supra notes 116-45 and accompanying text (chronicling the history of Latino school segregation). 


\section{THE FUTURE OF LATINOS AND SCHOOL DESEGREGATION}

This Note has argued that race and ethnicity are socially constructed concepts in which society instills meaning and that the Latino identity has been constructed in a self-contradictory manner-at once White and Non-White-because it does not fit within the BlackWhite binary through which Americans understand race. The issue of Latino identity is further complicated in the context of school desegregation because federal courts have moved from a BlackWhite to a White-Non-White binary. This new paradigm denies the history of segregation and discrimination against Latinos and fails to recognize the contemporary differences between Latino and African American experiences. As a result of this conceptual negligence, Latinos are denied the full benefits of Brown. The question that must be asked is what should be done to improve this difficult situation. In this final part, several alternatives will be proposed to minimize Latinos' educational segregation-including options that do not directly involve the courts.

\section{A. Racial and Ethnic Balancing in the Present System: Considering Latinos Separately}

The most obvious remedy to the present inequality would be to consider Latinos and African Americans separately for purposes of establishing racial and ethnic balance in school districts. In school districts with substantial African American, Latino, and White student populations, this approach might be both appropriate and feasible. Courts could consider this measure sua sponte, or the parties to the litigation could propose it. Although this measure would rely on some outmoded standards of racial and ethnic classification, such classification would address many of the issues discussed in this Note by making Latinos a visible group.

When courts acknowledge the history and contemporary situation of Latino students, they can craft remedial orders that consider those students' unique needs. The Supreme Court has held that every school in a community is not required to be a mirror image of the specific racial and ethnic composition in the surrounding community. ${ }^{243}$ Currently, courts overseeing school desegregation ensure that schools' enrollment approximates the White-Non-White balance in the community, but courts do not distinguish among Non-White

243. Swann v. Charlotte-Mecklenburg Bd. of Educ., 402 U.S. 1, 24 (1971). 
groups. Courts are not precluded, however, from considering Latino and African American students' distinct needs without binding districts to strict mandates of multi-group racial and ethnic balance where such balancing is impractical. Because of Latino students' concentration in large urban areas, ${ }^{24}$ many smaller school districts will have such a low percentage of Latino students that to consider them separately from African Americans for purposes of racial and ethnic balancing would be a logistical nightmare. In these situations, awareness of and attention to differences between Latinos and African Americans through means less restrictive than racial balancing would address present inequalities, especially when narrowly tailored to specific school systems. It also would promote desegregation of Latino students.

A few federal courts have taken the approach of viewing African Americans and Latinos as distinct groups without mandating racial balance, though these courts are the exception to the general rule of the White-Non-White paradigm. The federal district court in Denver (ironically, the site of origin of the Keyes litigation, which introduced the White-Non-White paradigm) considered Latinos and African Americans as distinct groups when issuing the finding of liability in $1970{ }^{245}$ Twenty-five years later, the court utilized these same categories when applying the six factors identified in Green v. County School Board ${ }^{246}$ and declaring that the district had achieved unitary status. ${ }^{247}$ Gaps between the hiring rates of Latino and African American faculty and staff, and between Latino and African American student dropout rates did not prevent the district from being declared unitary in light of its attempts to remedy those situations.

The different educational needs of Latino students are clearest in the context of bilingual education. Bilingual programs often are threatened during school desegregation litigation ${ }^{248}$ because of the

244. See CREATING THE WILL, supra note 217, at 23 (noting that in 1998 "the nation's 10 largest central city school districts collectively enrolled close to 25 percent of all Hispanic students, 18 percent of African American students, and only 2 percent of white students").

245. See Keyes v. Sch. Dist. No. 1, 313 F. Supp. 61, 69 (D. Colo. 1970) (noting that "the Hispanos have a wholly different origin, and the problems applicable to them are different").

246. 391 U.S. 430, 435 (1968).

247. Keyes v. Cong. of Hispanic Educators, 902 F. Supp. 1274, 1274 (D. Colo. 1995), aff'd, 119 F.3d 1437 (10th Cir. 1997). The trial court considered Latinos and African Americans as distinct groups while discussing faculty and staff hiring processes, 902 F. Supp. at 1296-98, student enrollment in the district's centralized gifted program, $i d$. at 1300 , student discipline, $i d$. at 1303, and student dropout rate, $i d$. at 1305.

248. Professor Gary Orfield notes that "[t]he [school desegregation] litigation is often brought into court by black organizations, with Hispanics becoming participants in a three-sided 
programs' tendency to group large numbers of Latino students in the same school. As recently as 1994, the General Accounting Office indicated support for bilingual education programs. ${ }^{249}$ In 1996, the President's Advisory Commission on Educational Excellence for Hispanic Americans endorsed bilingual education as "[ $t]$ he fastest and most effective way for bilingual students to acquire both a command of English and a command of classroom subject matter., ${ }^{250} \mathrm{Al}-$ though the Clinton administration strongly supported bilingual education, bilingual programs have been under attack by ballot initiatives and likely will not be supported by the George W. Bush administration, which appears to be focusing on achieving the result of English fluency rather than focusing on the pedagogical process. ${ }^{251}$ In just the past three years, bilingual programs have been "virtually eliminat[ed]" 252 by state voter initiatives in California and Arizona ${ }^{253}$ - two of the six states with the highest concentration of Latinos. ${ }^{254}$ In Cali-

struggle over the nature of the remedy, often fighting to preserve and expand bilingual education within the desegregation plan." Orfield, supra note 221, at 256.

249. See White House Initiative on Educ. Excellence for Hispanic Ams., supra note 218 (examining "some of the most serious inadequacies of the educational system for Latino students, including ... the lack of sufficient bilingual and English-as-a-Second-Language programs and teachers").

250. White House Initiative on Educ. Excellence for Hispanic Ams., Factors Affecting Hispanic American Educational Attainment, in Our Nation on the Fault Line: Hispanic American Education, at http://www.ed.gov/pubs/FaultLine/state2.html\#Factors (Sept. 1996) (on file with the Duke Law Journal).

251. See George W. Bush, No Child Left Behind, U.S. Dep't of Educ. (Jan. 29, 2001) (presenting the Bush proposal for achieving English fluency for all students), available at http://www.ed.gov/inits/proposal.pdf (on file with the Duke Law Journal); see also Don Soifer, Bush Bilingual Plan Offers Major Changes, SCH. REFORM News, Apr. 2001, at 1, 10 (describing some of the changes that would occur were the Bush plan implemented). President George W. Bush held this position during the campaign and at least since 1998. See David Koenig, Gov. Bush Supports Bilingual Education, SEATTLE TIMES, July 2, 1998, at A8 (describing Bush's endorsement of bilingual programs on the condition that such programs teach English to students); George W. Bush on Immigration, Issues 2000: Every Presidential Candidate's View on Every Issue, at http://www.issues2000.org/George_W_Bush_Immigration.htm (last visited Apr. 15, 2001) (citing Bush's proposal to "[r]espect other languages, but teach all children English") (on file with the Duke Law Journal).

252. Lynn Schnaiberg, Immigrants: Providing a Lesson in How to Adapt, EDUC. WK., Jan. 27,1999 , at 34,35 .

253. Both the California and Arizona ballot initiatives were spearheaded by California Republican (and unsuccessful gubernatorial candidate) Ron Unz. See DAVIS, supra note 5, at 122, 127 (detailing Unz's efforts in California and Arizona). In 2000, Arizona voters approved a measure that will replace bilingual education with "structured immersion" beginning in August 2001. The form of "structured immersion" has not yet been defined. Bilingual Legal Muddle Has Schools Under Fire: Federal Intimidation, Lack of Local Leadership, ARIZ. REPUBLIC, Jan. 23, 2001, at B6.

254. The six states with the greatest number of Latinos are, in descending order, California $(10,459,616)$, Texas $(6,045,430)$, New York $(2,660,685)$, Florida $(2,334,403)$, Illinois $(1,276,193)$, 
fornia, this proposition passed "despite the vehement opposition of 63 percent of Latino voters." 255 Additionally, the New York City public schools have recently approved a proposal that will allow parents to choose from among four language education programs. ${ }^{256}$ The need to balance schools racially and ethnically would not threaten bilingual programs if courts took a more pragmatic approach and considered Latinos' specific educational needs. Because of the successful ballot initiatives in California and Arizona, and the reduction of bilingual education in New York City, bilingual education might be eliminated long before such programs ever would be contemplated by courts. ${ }^{257}$

Uniform racial balance might need to be sacrificed to preserve bilingual programs, but given Latinos' social and economic disadvantages as a group, that sacrifice seems wholly appropriate and could be accomplished easily through a pragmatic approach. In his oversight of the Keyes litigation, Federal District Judge Richard Matsch specifically considered the role of bilingual education programs in the Denver desegregation remedial order from 1974 through $1985 .^{258} \mathrm{He}$ "brought the language issues into the mainstream of the desegregation litigation" by "not order[ing] a discrete remedy for the language issues but link[ing] their resolution to the creation of a unitary school system." 259 Importantly, the inclusion of bilingual education in the re-

and Arizona $(1,084,250)$. U.S. Census Bureau, Population Projections Program, Population Division, States Ranked by Hispanic Population, at http:/www.census.gov/population/estimates/ state/rank/hisp.txt (July 1, 1999) (on file with the Duke Law Journal). These population estimates were released in July 1999. Id.

255. DAVIS, supra note 5, at 122 .

256. Lynette Holloway, Board of Education Votes, 7-0, to Revamp Bilingual Programs, N.Y. TIMES, Feb. 28, 2001, at A1. The four programs from among which parents can choose include: (1) traditional bilingual education where core subjects are taught in the student's native language and other subjects are taught in English; (2) English as a Second Language (ESL) in which core subjects are taught in English; (3) a new after-school and weekend program for English language instruction; and (4) a dual language program. Id.

257. President George W. Bush has taken the easy way out by not endorsing either bilingual education or language immersion. Bush has attempted to endorse whatever works (without knowing what that is). See supra note 251 and accompanying text. However, the effectiveness of bilingual education versus immersion is the subject of extensive pedagogical debate. See, e.g., White House Initiative on Educ. Excellence for Hispanic Ams., supra note 218 (advocating the implementation of bilingual educational programs as the best way to ensure teaching of the English language and of academic subject matter). For an overview of immersion programs, see ERIC Digest, Foreign Language Immersion Programs, at http://www.cal.org/ericcll/digest/ met00001.html (Nov. 1993) (on file with the Duke Law Journal).

258. James J. Fishman \& Lawrence Strauss, Endless Journey: Integration and the Provision of Equal Educational Opportunity in Denver's Public Schools: A Study of Keyes v. School District No. 1, in Justice AND SCHOOL Systems: THE Role OF THE COURTS IN EDUCATION LiTIGATION 185, 208 (Barbara Flicker ed., 1990).

259. Id. 
medial order did not alter the remedial plan so much as to require the reassignment or dislocation of White students. ${ }^{260}$ Keyes demonstrates that a strong bilingual education program can coexist with a successful desegregation order. As shown in Denver, federal courts have the ability to recognize the differences between Latino and African American students and to respond accordingly. The more radical question, though, is whether the courts are the correct forum in which to pursue racial equality.

\section{B. To Be or Not to Be (in Court)?}

The Keyes case was filed in 1968. Federal court supervision ended when a district judge declared the district unitary in 1995, and the end of court supervision was confirmed in 1997 when the Tenth Circuit approved the declaration of unitary status. The Denver school district's thirty-year supervision period is not uncommon, and Judge Matsch's closing comments in his final order in Keyes bear consideration:

This case has not been unique. It is but one of many such cases across the country. What is most common in the history of all those cases is uncertainty. Thousands of pages have been written by scores of federal judges attempting to articulate guiding principles under the broad constitutional concept announced in Brown v. Board of Education. What has been demonstrated most clearly is that courts using the adversary system were not designed to accomplish institutional reform. The Supreme Court has recognized in its most recent relevant opinions that the framers of the Constitution put their faith in the people and the democratic process to determine and provide for the general welfare. ${ }^{261}$

In many ways, it is nearly fifty years too late to ask the question of whether federal courts are the appropriate body to oversee each detail in the process of implementing Brown. Both liberals and conservatives question this judicial role, though for profoundly different reasons. ${ }^{262}$ If opposing political groups came together to support curtailing-or even ending-judicial intervention in school desegregation

260. See id. at 220 (contrasting the burdens of this remedy with those of busing).

261. Keyes v. Cong. of Hispanic Educators, 902 F. Supp. 1274, 1307 (D. Colo. 1995) (citation omitted).

262. Neal Devins, The Judicial Role in Equality Decisionmaking, in REDEFINING EQUALITY, supra note 170, at 218, 227 (noting that "some progressives and many conservatives oppose judicial intervention," although for different reasons). 
oversight, it certainly would not be the first time that politics made strange bedfellows in the area of educational policy. ${ }^{263}$ Working outside a judicial framework to resolve school segregation would not require courts to change the Supreme Court's White-Non-White paradigm but could allow instead for the easier creation of a new paradigm in a context where no previous frameworks exist.

School desegregation measures were implemented in communities across the United States in the late 1960s and early 1970s in the absence of litigation or involvement by the Department of Health, Education, and Welfare. Desegregation efforts in Colorado Springs, Colorado, in Stamford, Connecticut, and in Berkeley, California, all relied on strong community involvement in formulating plans for desegregation. ${ }^{264}$ Although the leadership of school district superintendents and school boards was important in initiating desegregation efforts, citizens' advisory committees and open forums kept community members aware of the school boards' evolving plans. ${ }^{265}$ These "success stories" reinforce Professor Gerry Spann's argument that the political process, rather than federal courtrooms, is the most effective forum in which to pursue equality. ${ }^{266}$ However, these examples should not be taken to mean that "courts will not play even a limited role in "permitting change." ${ }^{267}$ As many argue, litigation "must be linked to a broader-based political and social movement, ${ }^{, 268}$ as illustrated by the first school desegregation order in Lemon Grove, California.

263. Consider, for example, the current school voucher movement that is supported by liberals who believe public schools are failing the most disadvantaged children (often working class African American and Latino children), and conservatives who believe that parents should not be forced to support financially a school system from which they derive no direct benefit.

264. Conn. Advisory COMM. TO THE U.S. COMM'N ON CIVIL Rights, SCHOOL Desegregation in Stamford, Connecticut 14 (July 1977); StafF RePORT OF THE U.S. COMM'N ON CIVIL Rights, SCHOOL DESEGREGATION IN BERKELEY, CALIFORNIA 4, 9 (Aug. 1977); STAFF REPORT OF THE U.S. COMM'N ON CIVIL RIGHTS, SCHOOL DESEGREGATION IN COLORADO SPRINGS, COLORADO 3, 6, 11 (Feb. 1977).

265. CONN. AdVISORY COMM. TO THE U.S. COMM'N ON CIVIL Rights, SCHOOL Desegregation In StAMFord, CONNECTICUT 14 (July 1977); STAFF RePORT OF THE U.S. COMM'N ON CIVIL Rights, SCHOOl DeSEgREgation IN BERKELEy, CALIFORNia 4, 9 (Aug. 1977); STAFF REPORT OF THE U.S. COMM'N ON CIVIL RightS, SCHOOL DESEGREGATION IN COLORADO SPRINGS, COlORADO 3, 6, 11 (Feb. 1977).

266. Girardeau A. Spann, Race Against the Court: The Supreme Court and MINORITIES IN CONTEMPORARY AMERICA 4-5 (1993).

267. Jerome M. Culp, Jr., Black People in White Face: Assimilation, Culture, and the Brown Case, 36 WM. \& MARY L. REV. 665, 670 (1995).

268. Kevin R. Johnson, Civil Rights and Immigration: Challenges for the Latino Community in the Twenty-First Century, 8 LA RAZA L.J. 42, 55 (1995); see also Culp, supra note 267, at 670 (making the same argument about the dangers of overreliance on litigation). 
Liberals who note "the despair and suffering of poor black, Native American, Latino(a) and Chicano(a) children" express skepticism of the "paradigm that asks us to place our hopes for radical social transformation in the courts of this land." ${ }^{, 69}$ And this skepticism is well-earned. Aside from the question of whether desegregating schools is an appropriate task for federal courts, critics of desegregation often cite cases like the court-supervised desegregation of Boston's public schools where decades of federal intervention resulted in higher segregation and lower test scores. ${ }^{270}$ Another situation that has generated high costs (quite literally) is the Kansas City case, Missouri v. Jenkins. ${ }^{271}$ Jenkins has resulted in dramatic "White flight" in the Kansas City school district. The district court reacted to this demographic change by approving enormous financial expenditures to create magnet schools, ${ }^{272}$ but those new schools ultimately have been ineffective at luring White students back into Kansas City's public schools. ${ }^{273}$

One alternative to traditional judicial oversight is to enlist a small group of educational professionals to implement the court-ordered remedy. The group's work would be loosely overseen by the courts. These education specialists would not be imbued with nearly the whole of the court's authority, as are the court-appointed "masters" who oversee school districts throughout the country. ${ }^{274}$ Additionally,

269. Hazel Carby, Can the Tactics of Cultural Integration Counter the Persistence of Political Apartheid? Or, the Multicultural Wars, Part Two, in RACE, LAW AND CULTURE: REFLECTIONS ON BROWN V. BOARD OF EDUCATION 221, 226 (Austin Sarat ed., 1996) [hereinafter RACE, LAW AND CULTURE].

270. Jeremy Rabkin, Racial Divisions and Judicial Obstructions, in REDEFINING EQUALITY, supra note 170 , at 82,92 .

271. 515 U.S. 70 (1995).

272. In 1995, the total cost of capital improvements ordered by the district court to remedy de jure segregation in Kansas City's public schools exceeded \$540 million. Id. at 78. The funds were used for:

high schools in which every classroom will have air conditioning, an alarm system, and 15 microcomputers; a 2,000-square-foot planetarium; green houses and vivariums; a 25 -acre farm with an air-conditioned meeting room for 104 people; a Model United Nations wired for language translation; broadcast capable radio and television studios with an editing and animation lab; a temperature controlled art gallery; movie editing and screening rooms; a 3,500-square-foot dust-free diesel mechanics room; 1,875-square-foot elementary school animal rooms for use in a zoo project; swimming pools; and numerous other facilities.

Id. at 79 .

273. Id.

274. See generally David L. Kirp \& Gary Babcock, Judge and Company: Court-Appointed Masters, School Desegregation, and Institutional Reform, 32 ALA. L. REV. 313 (1981) (discussing the role of masters in school desegregation generally and analyzing masters' performance in six northern school districts specifically). For a criticism of courts' deference to masters, see Donald 
this group would work with the litigants and act more as mediators than as judges. In the early stages of school desegregation litigation, parties should explore extra-legal means of alternative dispute resolution as an avenue for creating an initial remedial agreement without filing a claim in court. Federal courts will retain ultimate authority, however, because they wield the force of law.

While judicial intervention certainly has not been comfortable or without cost, the deluge of desegregation litigation during the last fifty years has unquestionably reinforced the idea that the government cannot intentionally discriminate against individuals on the basis of their race or ethnicity. Given the high standards of "intent" which the courts require to determine that a school district is liable for segregating its students, ${ }^{275}$ and the much more subtle and normalized ways in which racism pervades our society as demonstrated by the concept of White privilege, ${ }^{276}$ another wave of school desegregation litigation is unlikely. In light of the past forty-five years of school desegregation litigation and federal judicial oversight, a school district that is alleged to have segregated its students on the basis of race or ethnicity would be well advised to take fast and dramatic steps to reinforce racial and ethnic equality within its system and settle any claims long before they proceed to trial. The costs of discovery and litigation are financially damaging, and litigation is detrimental to the morale of the school district and the community.

The complicated history of school desegregation efforts suggests that the most effective solution for Latinos' present inequality does not include exclusive reliance on the courts. To achieve the goal of

L. Horowitz, Decreeing Organizational Change: Judicial Supervision of Public Institutions, 1983 DUKE L.J. 1265, 1297-1302.

275. Though the standards are high, they are not uniform, with various circuits giving different weight to objective and subjective elements of intent. The Second Circuit balances subjective and objective elements of intent by "holding that foreseeable consequences, while not specifically identifiable with intention, can provide evidence for its presence." Arthur v. Nyquist, 573 F.2d 134, 142 (2d Cir. 1978). The Fifth Circuit aligns itself with the Second Circuit, though the Fifth Circuit professes to have adopted a purely objective test. United States v. Tex. Educ. Agency, 564 F.2d 162, 167-68 (5th Cir. 1977). The Sixth Circuit permits a finding of segregatory intent to be "inferred from acts and policies of school authorities which had the natural and foreseeable effect of producing segregated schools." NAACP v. Lansing Bd. of Educ., 559 F.2d 1042, 1047 (6th Cir. 1977). In the same breath, however, the Sixth Circuit takes care to distinguish itself from the "'discriminatory effect' test repudiated in Washington v. Davis and Austin Independent School District v. United States." Id. (citations omitted). At the other extreme, the Ninth Circuit requires a "determination that the school authorities had intentionally discriminated against minority students by practicing a deliberate policy of racial segregation." Soria v. Oxnard Sch. Dist., 488 F.2d 579, 585 (9th Cir. 1973).

276. For a description of White privilege, see supra notes 231-37 and accompanying text. 
equal educational opportunity for all students, including Latinos, the responsibility for ensuring racial and ethnic equality must not end with a judge. The goal of desegregation litigation continues to be to "increase the ability of public schools to break the link between the social, political, and economic circumstances of one generation and the next." ${ }^{277}$ The more responsibility local communities and school boards take for ensuring Latinos equal educational opportunity, the less the federal courts will need to flex their collective muscle.

\section{Secondary School and Legal Education}

My final suggestions involve ways to begin reconstructing race and ethnicity to include the Latino narrative. These measures go to the root of the problem of Latino school segregation. As explained above, Latinos suffer from higher rates of school segregation because they are not considered distinct from African Americans and are rendered invisible in a White-Non-White paradigm by a society that never learns about Latinos' unique history and present experiences. ${ }^{278}$ The reason that the socially constructed nature of race and ethnicity is important is that, because they are constructed to begin with, these concepts theoretically can be reconstructed. The process of reconstruction entails changing the norm-the way society thinks about a concept-a task fraught with difficulty. ${ }^{279}$ Thus, the following suggestions are limited to concrete ways the education system can be used to dismantle the White-Non-White paradigm by integrating the Latino narrative into the teaching of American history and law.

Some scholars argue that continuing to focus on race and ethnicity merely perpetuates racism by endorsing a race- and ethnicity-

277. Denise C. Morgan, The Less Polite Questions: Race, Place, Poverty and Public Education, 1998 ANN. SURV. AM. L. 267, 276 (1998).

278. See infra notes $288-96$ and accompanying text.

279. Professors Richard Delgado and Jean Stefancic describe a reconstructive paradox as consisting of six parts, which can be thought of sequentially: first, the greater a social evil, the more likely it is to be entrenched; second, the more entrenched the evil, the greater the social effort required to dislodge that evil; third, the harm of the evil is invisible to many because the harm is normalized; fourth, a social effort inevitably conflicts with normalized social values and would significantly shift the way we interact with each other; fifth, those shifts in our interactions are highly visible because they clearly oppose the norm and thus cause massive backlash; and sixth, supporting the backlash seems appropriate because the radical social instigators are sacrificing commonly held values for some nebulous goal. Richard Delgado \& Jean Stefancic, The Social Construction of Brown v. Board of Education: Law Reform and the Reconstructive Paradox, in ReDEFINING EQUALITY, supra note 170, at 154, 160. 
focused worldview. ${ }^{280}$ Rather than a "colorblind" view of race, I endorse a "multicultural" view of race and ethnicity. ${ }^{281}$ Racism will not cease to exist merely because we ignore it. Rather, it will cease to exist when we recognize, understand, and dismantle the system of White privilege that supports it. A crucial step in this change is understanding the ways White privilege is reinforced by the White-Non-White dichotomy that defines all groups in relation to the White norm. ${ }^{282}$

The history and contemporary experience of Latinos is increasingly taught in secondary schools. A standard high school American history book includes a discussion of the Mexican-American War, ${ }^{283}$ Latinos' participation in World War II, ${ }^{284}$ and the Latino civil rights movement. ${ }^{285}$ This text was reviewed by nine historians, one of whom specializes in Latino history. ${ }^{286}$ A standard American history book used in Advanced Placement courses also acknowledges the involvement of Latinos in American history. ${ }^{287}$ The inclusion of Latino history in these textbooks is a great step towards breaking down the

280. Richard Payne's argument illustrates this point: "The habitual use of terms like 'race' and 'racism' almost guarantees a racial worldview or perspective will be perpetuated. The stereotypes that are integral components of a racial perspective are often subconsciously accepted not only by those who gain but also by those who are disadvantaged by their existence." PAYNE, supra note 25, at 11. Jeremy Rabkin's comment falls along a similar trajectory: "The more explicit the race-conscious element in law, the more it teaches whites that blacks cannot compete on their own and the more it teaches blacks that whites are too irredeemably racist to afford fair treatment to all races without coercion." Rabkin, supra note 270, at 85 .

281. Gary Peller defines multiculturalism as

the notion that American society should be understood as a collection of diverse cultural groups rather than as a single, unified national body on one hand or as simply an aggregate of atomized individuals on the other.... [A] multiculturalist sensibility implies that the government must recognize and respect if not nurture the diversity and integrity of racial and ethnic communities.

Gary Peller, Cultural Imperialism, White Anxiety, and the Ideological Realignment of Brown, in RACE, LAW AND CUlTURE, supra note 269, at 190,193. He continues,

The contemporary emergence of multiculturalism is ultimately traceable to various historical factors, and it is only partial; nevertheless, it also seems clear that one of its main, established tenets has been the idea of acknowledging and respecting difference, rather than assuming, like the Brown consciousness seemed to, that there was a neutral, acultural institutional reality, in public schools or any other places, that would transcend race.

Id. at 209.

282. See supra notes 231-39 and accompanying text.

283. Andrew CAyton et Al., America: PATHWAys to the PRESENT 276-80 (1998).

284. Id. at 706-11.

285. Id. at 831-33.

286. Id. at vi.

287. See Paul S. Boyer et Al., The Enduring Vision: A History of the American PEOPLE 361-73 (2000) (chronicling the American settlement of Texas and the development of the Mexican-American War); id. at 740-44 (analyzing Latinos' economic condition during the Great Depression); id. at 835-36 (discussing the Latino civil rights struggle). 
Black-White binary and the White-Non-White paradigm, and recognizing differences among racial and ethnic groups in the United States.

This recognition of the Latino narrative is often overlooked in legal education, especially in the area of constitutional law-a required first-year course in law schools across the United States. Of six leading constitutional law casebooks, four overlook the topic of Latinos in connection with school desegregation. Because of the unique questions presented in Keyes $v$. Denver, it would be easiest for casebooks to include the discussion of Latinos in their discussion of Keyes, especially since most of the texts that omit a discussion of Latinos in school desegregation already cite Keyes for other purposes. The three texts edited by Professor William Lockhart, ${ }^{288}$ Professor Geoffrey Stone, ${ }^{289}$ and Professors Gerald Gunther and Kathleen Sullivan, ${ }^{290}$ all cite Keyes in a condensed or excerpted form and focus on the development of the standard of discriminatory intent. The text edited by Professor Donald Lively includes a brief textual discussion of Keyes, but, again, for other purposes. ${ }^{291}$ These four texts devote a total of 475 pages to discussions of race and ethnicity and equal protection including a total of 128 pages devoted to school desegregation cases and commentary. ${ }^{292}$

Two other constitutional law textbooks address the racial and ethnic aspect of Keyes, and thus the involvement of Latinos in school desegregation litigation. Professors William Cohen and Jonathan D.

288. William B. Lockhart et AL., Constitutional Law 1206 (8th ed. 1996).

289. Geoffrey R. Stone et Al., Constitutional LaW 533-35 (3d ed. 1996). The only indexed discussion of Latinos in this 1814 page book was in reference to Hernandez v. New York, 500 U.S. 352 (1991), a case permitting the use of peremptory challenges to strike Latino jurors because of the Court's concern that Spanish-speaking jurors would reject the Court's English translations of Spanish-speaking witnesses' testimony in favor of the actual, untranslated testimony of such witnesses. See STONE, supra, at 630-31.

290. Gerald Gunther \& KathleEN M. Sullivan, COnSTitutional LAW 776-77 (13th ed. 1997).

291. Donald E. Lively et al., Constitutional Law: Cases, History, and DIALOGUES 706 ( $2 \mathrm{~d}$ ed. 2000). In a separate section, the Lively text parenthetically mentions Latinos' benefits from affirmative action as part of a discussion of the benefits African Americans have received from affirmative action. Id. at 810-11.

292. See GUNTHER \& SULLIVAN, supra note 290, at 662-81 (discussing race discrimination and equal protection); id. at 673-77, 680-81 (discussing school desegregation); LIVELY ET AL., supra note 291, at 647-825 (discussing racial equality); id. at 685, 690-719, 721-27 (discussing school desegregation); LOCKHART ET AL., supra note 288, at 1163-1270 (discussing race and ethnic ancestry); $i d$. at 1171-79, 1200-19, 1220-22, 1223-26, 1244-45 (discussing school desegregation); STONE ET AL., supra note 289, at 495-567, 595-697 (discussing racial equality and equal protection); $i d$. at 518-61 (discussing school desegregation). 
Varat's text amply discusses this aspect of Keyes, ${ }^{293}$ and Professor Ronald Rotunda's textbook includes a brief excerpt from this aspect of the Supreme Court's opinion in Keyes. ${ }^{294}$ These two texts dedicate a total of 118 pages to cases and commentary about race and ethnicity and equal protection, including a total of sixty-seven pages to school segregation. Additionally, the leading education law casebook edited by University of Minnesota President Mark Yudof and Professors David Kirp and Betsy Levin addresses the unique racial and ethnic issues present in Keyes and the position of Latino students in school desegregation. ${ }^{295}$ The Yudof text provides a substantial excerpt from the Supreme Court's decision as well as additional commentary. ${ }^{296}$ Not surprisingly, this text allocated 119 pages to issues of race and ethnicity and equal protection, including 91 pages discussing school segregation. $^{297}$

If lawyers are not taught about the history of Latino educational segregation, it is not surprising that even those who work as advocates for social justice might not appreciate the importance of distinguishing between Latinos and African Americans-and avoiding constituting them as one Non-White group. Changes to these law school texts would be only a first step. Professors must also teach Keyes not only as a case that changed the standard of segregative intent and brought desegregation to the North, but also as a decision instituting the White-Non-White paradigm.

Schools are the site of the iteration of knowledge. Value-based judgments are implicit in what is deemed worthy to be taught. Those judgments are communicated, perhaps unconsciously and almost certainly unintentionally, through textbooks and classroom discussions. Therefore, changing the content of what is taught not only changes the base of knowledge, but also alters widely held social assumptions

293. CONSTITUTIONAL LAW: CASES AND MATERIALS 721-22 (William Cohen and Jonathan D. Varat eds., 10th ed. 1997); $i d$. at 592-743 (discussing suspect classifications and racial minorities); id. at 706-743 (discussing school desegregation); id. at 702 (discussing Hernandez).

294. Ronald D. Rotunda, MOdern CONSTITUTIONAL LAW: CASES AND Notes 641 (6th ed. 2000); id. at 619-84 (discussing racial equality); id. at 626-84 (discussing school desegregation); id. at 641 (mentioning Latinos).

295. MARK G. Yudof ET AL., EduCATiOnAl Policy AND THE LAW 533-35 (3d ed. 1992).

296. The forthcoming edition of this text, MARK G. YUDOF ET AL., EDUCATIONAL POLICY AND THE LAW (4th ed. forthcoming 2001) retains this discussion. See E-mail from Betsy Levin, Professor of Law, Nova Southeastern University, Shepard Broad Law Center, to Kristi L. Bowman (Jan. 29, 2001) (on file with the Duke Law Journal).

297. YUDOF ET AL., supra note 295, at 469-587 (discussing equal opportunity and race); $i d$. at 469-559 (discussing school desegregation). 
that serve to reinforce the exclusion of Latinos and render them invisible.

\section{CONCLUSION}

This Note has drawn together many concepts to argue that the current situation, in which Latinos are made invisible in the WhiteNon-White paradigm of school desegregation, is not just. Nor is it inevitable. The Latino identity has been constructed by many forces, including various branches of the federal government, in confusing and often conflicting ways. The unique identity of Latinos is important because of Latinos' common experience in the United States, an experience distinct from African Americans' and with which it should not be conflated. School desegregation, however, has collapsed the Latino narrative, first rendering it homeless in the Black-White binary that was the legacy of Brown, and then rendering it invisible in the White-Non-White paradigm that was the legacy of Keyes. Recognizing Latinos as a distinct group is inconsistent with both the Black-White and the White-Non-White paradigm, and thus it would threaten the privilege connected to those binaries. Latinos are a significant percentage of our nation's population, though, and are becoming a greater percentage every day. Maintaining paradigms that allow for the greater educational segregation of Latinos is inconsistent with the spirit-if not the letter-of Brown. 


\begin{abstract}
APPENDIX
In 1930, the school board in Lemon Grove, California, built a barn-like structure that was intended to serve as a separate school for the district's Latino students. Previously, the Latino children had attended the same school as all the other students in the small district. The Latino parents protested this de jure segregation, ultimately suing the Lemon Grove school board in the San Diego County courts. Breaking with the traditions of its time, the court held in 1931 that the Latino students could not be segregated from the White students and that the school district should return to the previous integrated school system. This case, Alvarez v. Owen, is the first known successful school desegregation case. Brown v. Board of Education was decided fifteen years later. The judgment in this case and the peremptory writ of mandate (the remedial order) exist only on aging microfilm in San Diego County. For the historical record, they are reprinted here. The case was not appealed and was never recorded in the official minutes of Lemon Grove school board meetings.
\end{abstract}



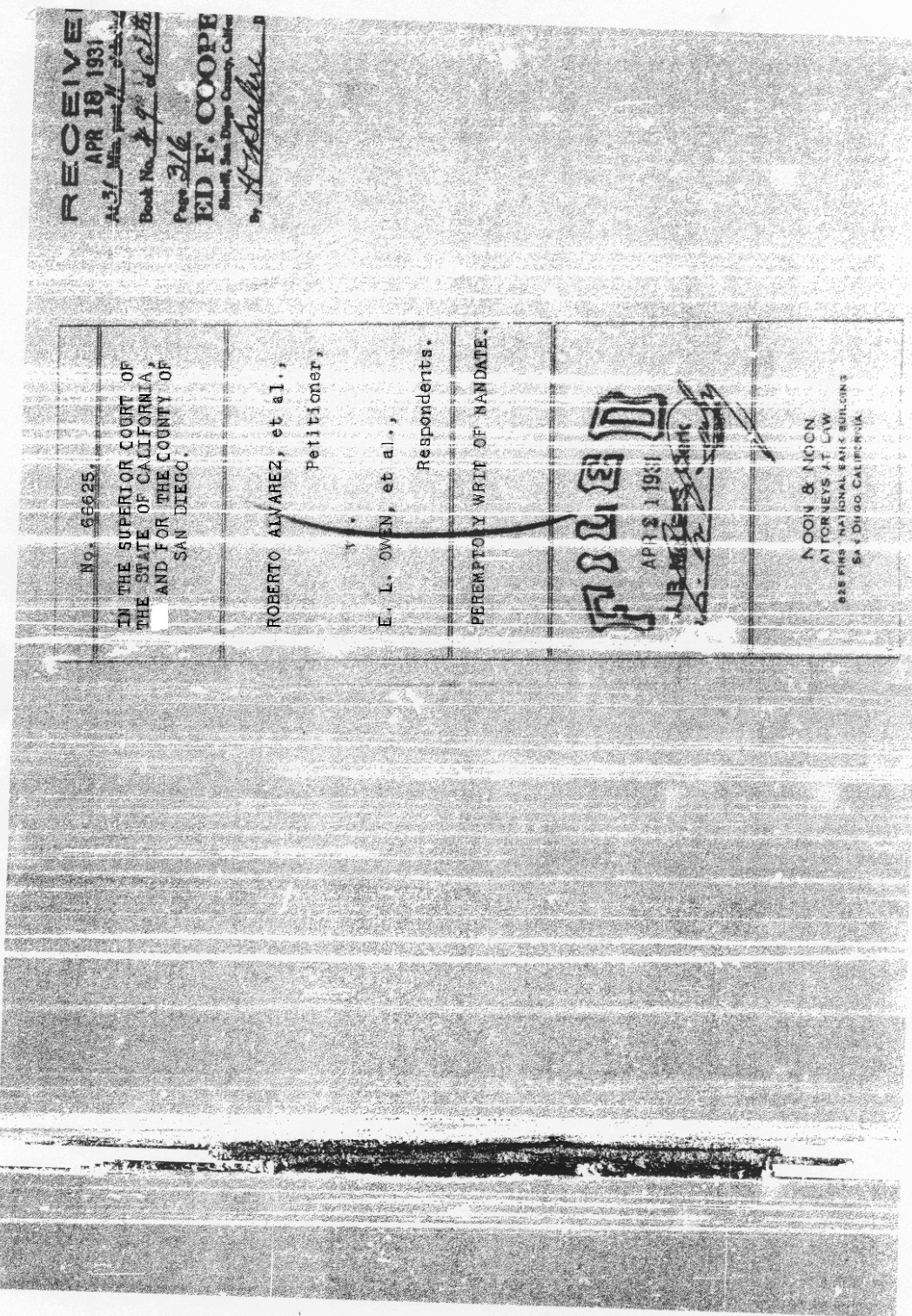


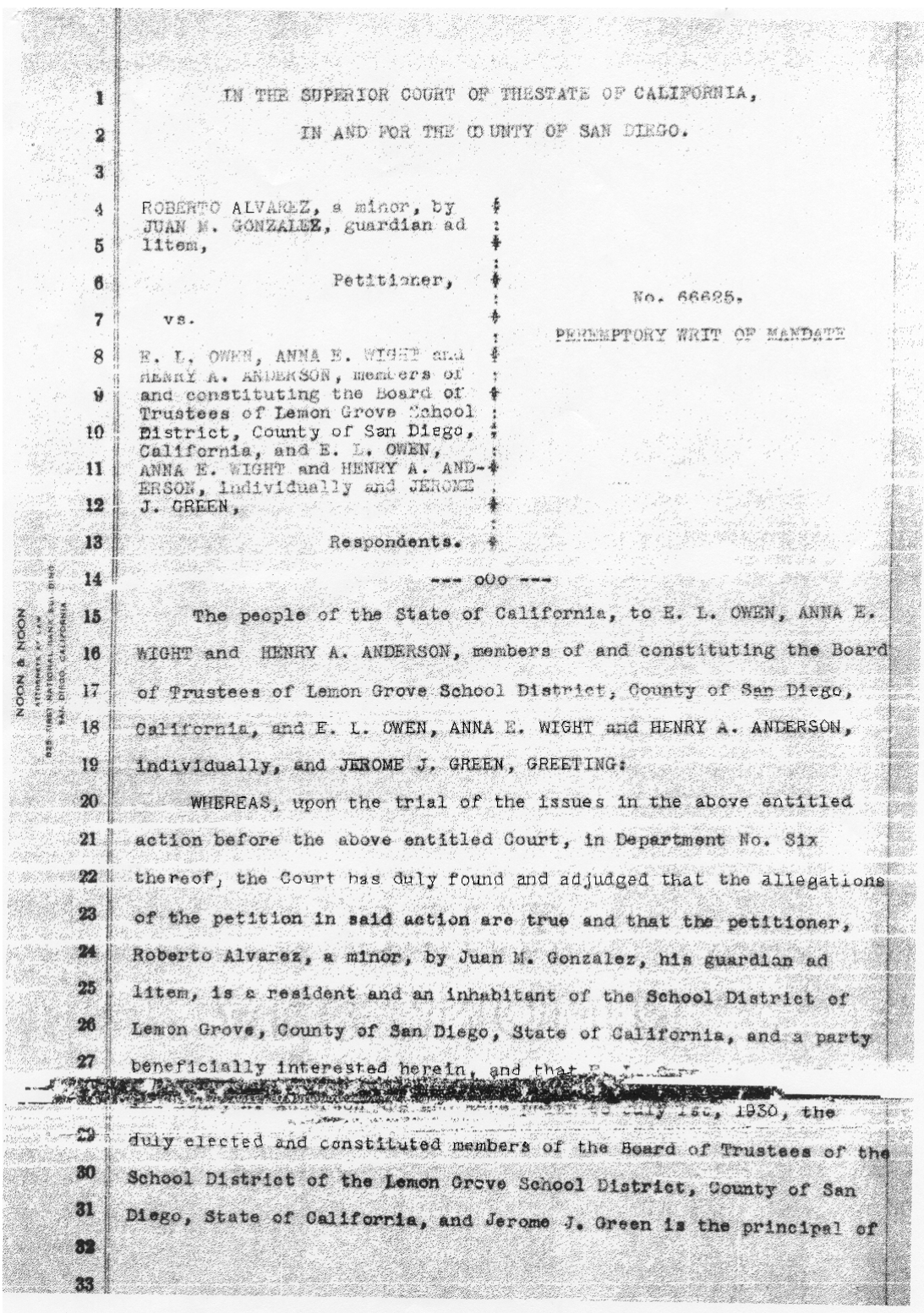


sald school, and that the school bullding of the school Distrelct of Lemon Grove, is a commodlous and nodern sohool bullatng, heving fivo elass rooms and flve teacherg regulardiy employed, sxd thet prion to the 5th dsy of January, 1931, Robert,o Alvarez, and about seventyfour other pupils of Mexican parentage, were regulariy attending and receiving instruction in sald fivo coom school buldatre, and on the moming of the 5th day of January, 1931, all of sald puplis of Mexican parentage were excluded from sald five room schood building, by action of the respondents above named, and that petittoner, and about seventy other puplis of Mexiean parentage, finding themselves exturned to thelr homes, and thereafter did not attend school and have not attended school since excluded therefrom on the sth day of January, 1931 ; and that prior to $3 \mathrm{Ald}$ date there had been constructed oy sald school trustioos a two room gehool buldalng and the exclusion of said pupils from the flve room school bullatng was an attampt to separate tive pupils of hexican parentage from all other puplis attending seld school, and to segregate the puptis of Mexican parentage in a separate school in the two room sehool bual- I ding apart from the other puplls attending school in se1d elve room school buklding, and that thore is no pla in, epeedy and adequate Femedy at law, and the laws of the state of Callfornia do not author1ze or permit the sstablishment of maintenance of for the Inatruction of pap1ls of Mextean parentaze, nationality and or descent, and the Bonrd of Sohool Trustees of Lemon crove Bohoul if D1 strict, vero and are without power to establish and maintin a seperate school for the Instruction of pup1ls or Mexican parentage, nationallty and/or descent, and that Roberto Alvarez and all other

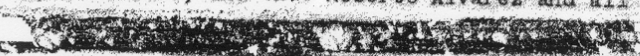

30 In the boundarles of Lemon Gxave sotoot Dist al fohool as aforesaid, were and are 20 gally ont1tled to enter agld 


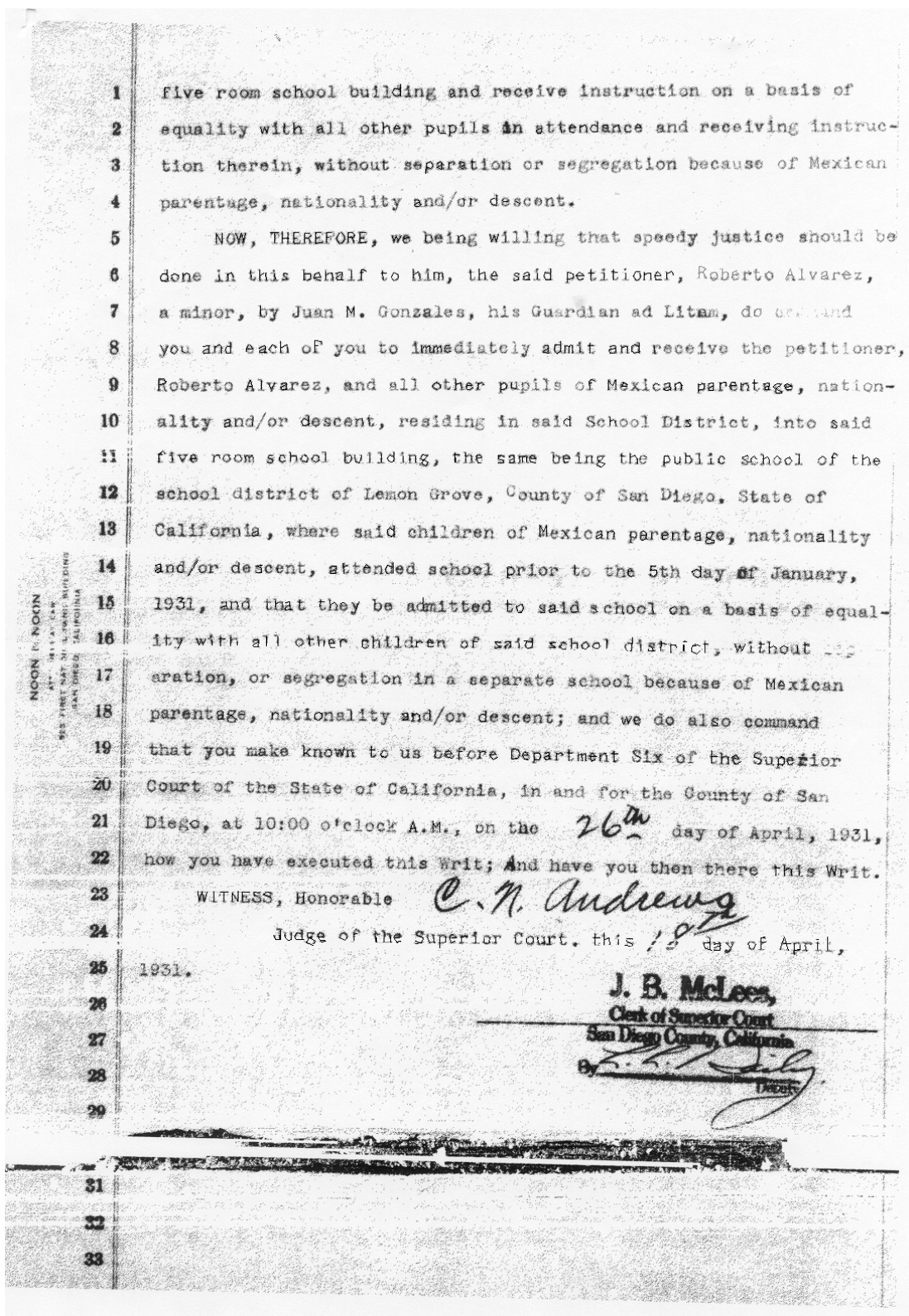




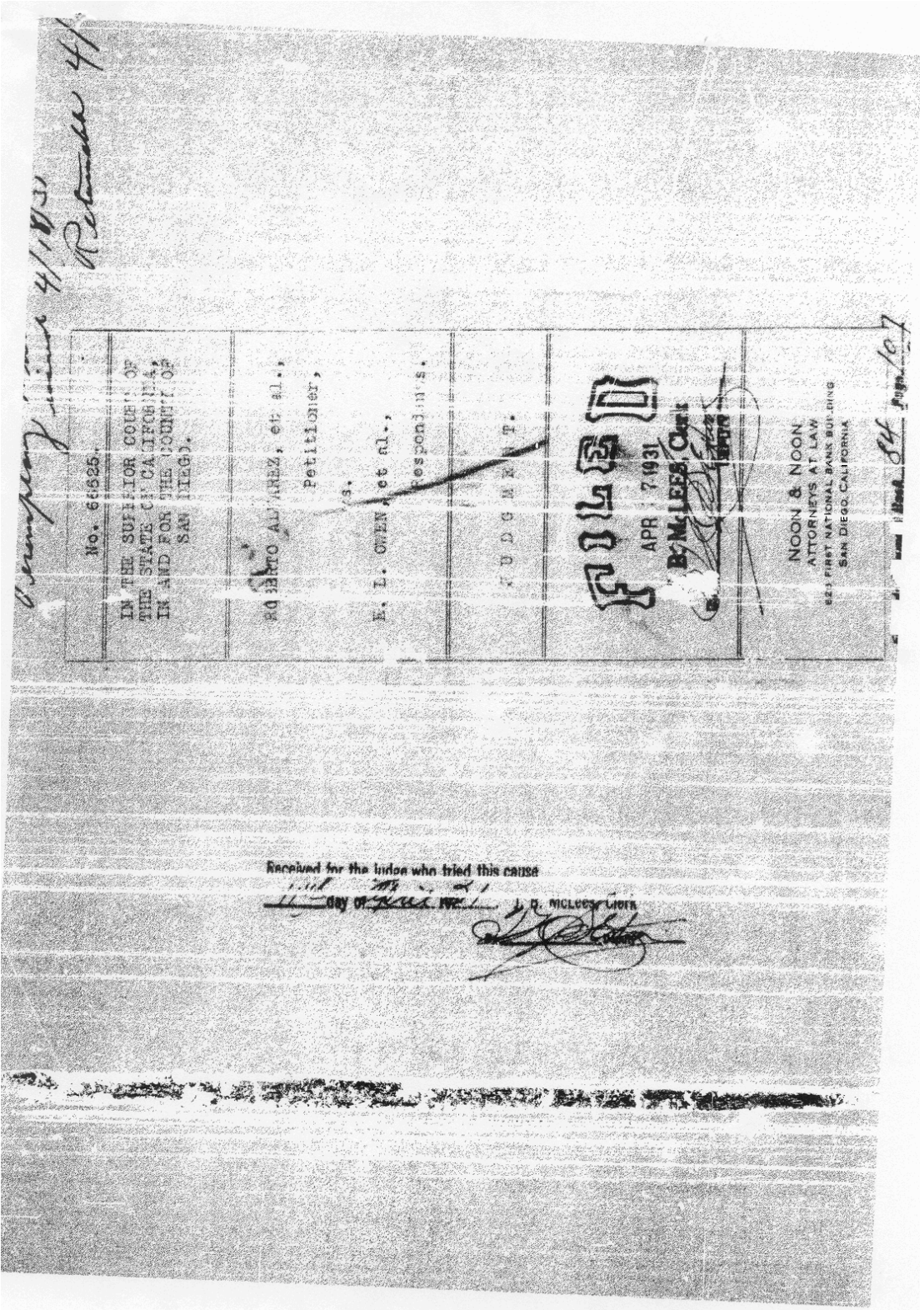




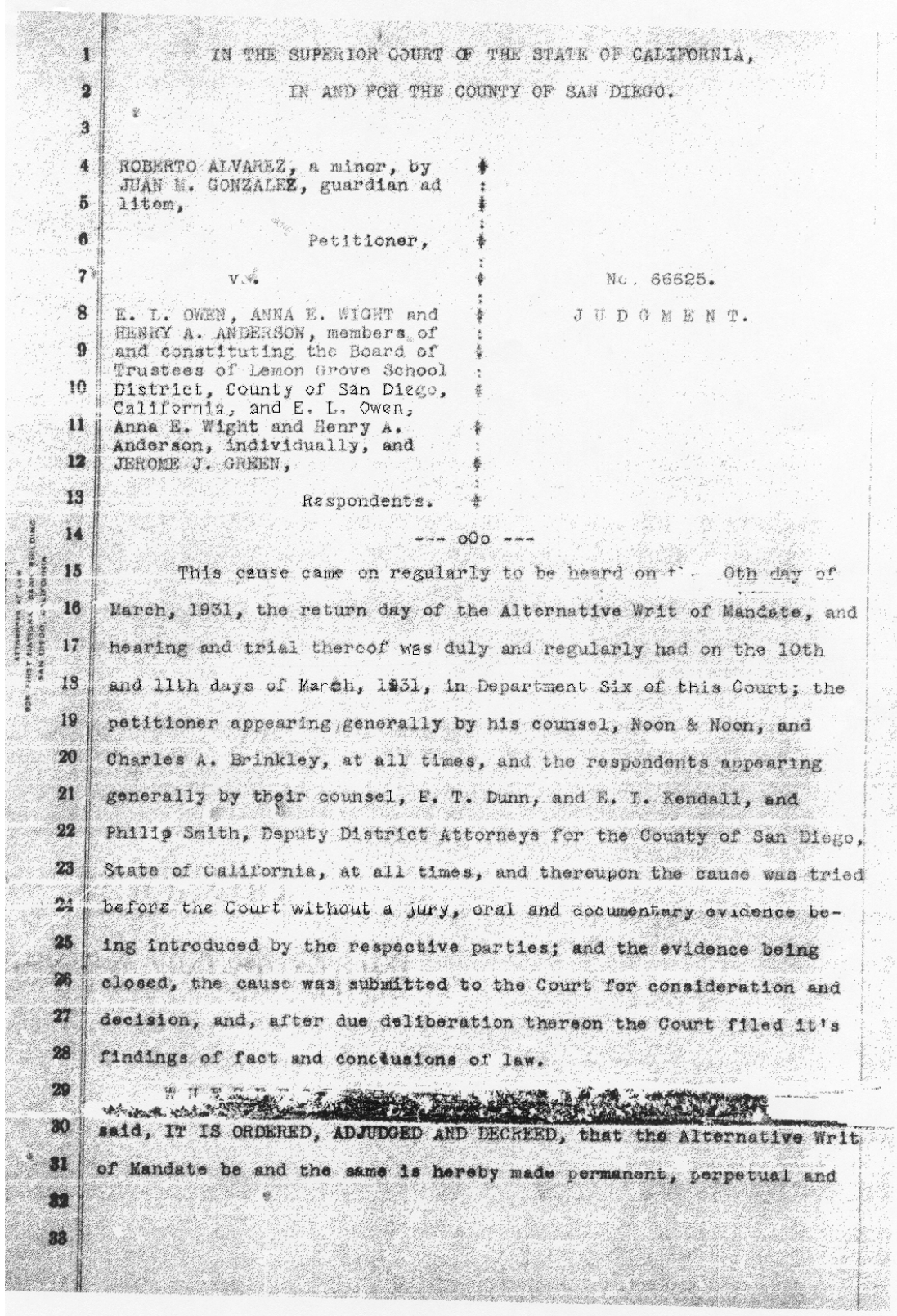


flinal, and that the Board of School 2matees of the School D1strict of Lemen Grove, County of San Dlego, State of California, pay all coats herotofore axpented by the petitioner hereln, taxed at $\$ 85.50$.

IT IS FURTHER ORDERED AND ADJUDEED by the Court that the prayer of the petitioner herein be and the same is granted, and the clerk of the superior Count is hereby oriered and directed to issue a peremptory wrst of kandate, herein conmanding $\mathrm{E}$. L. Onen, Anna k. Wght and Henry A. Arderson, members of and constituting the Board of Trustees of the School District of Lemon Grove, County of San Diego, State of Californit, and Jerone J. Green, principal of sala school, and each of them, respondents horeln, to 1madiately admit, and receive the petitioner, Roberto Alverez, and ali other pup1ls of Mexican parentage, nationality and/or descent, residing In sald school distriet, into sald flve rooms chool bullaing, the same belng the priblic school of the school distriet of Lemon frove, County of San Dlego, State of Calformia, where sald children of Mexican prentage, nationalicy and/or descent attended school prior to the 5th day of January, 1931, and that they be admitted to s ald school on a basis of equality with all other chlidren of said sehool district, without separation or segregation in a separate school because of Mexican papentage, nationality anc/or descent; and that sala Poremptory Writ of Hanatie be made returnable on the 26 th asy of Apr11, 1931, at 10:00 0' clock A.NF., before the fionorable

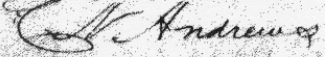
, in Depar went No., If of this Court, and for additioncl costs for service of sald Peremptory Writ of Mardate in the sum of Daced this $/ 6 \not$ day of Apr11, 1932. 